\title{
Quality of the Governing Temperature Variables in WRF in relation to Simulation of Primary Biological Aerosols
}

\author{
C. A. Skjøth, ${ }^{1}$ M. Werner, ${ }^{1}$ M. Kryza, ${ }^{2}$ B. Adams-Groom, ${ }^{1}$ A. Wakeham, ${ }^{1}$ \\ M. Lewis, ${ }^{1}$ and R. Kennedy ${ }^{1}$ \\ ${ }^{1}$ National Pollen and Aerobiology Research Unit, Institute of Science and the Environment, University of Worcester, \\ Henwick Grove, Worcester WR2 6AJ, UK \\ ${ }^{2}$ Department of Climatology and Atmosphere Protection, University of Wrocław, Ulica Kosiby 8, 51-621 Wrocław, Poland \\ Correspondence should be addressed to C. A. Skjøth; c.skjoth@worc.ac.uk
}

Received 9 April 2015; Revised 23 June 2015; Accepted 16 August 2015

Academic Editor: Enrico Ferrero

Copyright (C) 2015 C. A. Skjøth et al. This is an open access article distributed under the Creative Commons Attribution License, which permits unrestricted use, distribution, and reproduction in any medium, provided the original work is properly cited.

\begin{abstract}
We have evaluated three prognostic variables in Weather Research and Forecasting (WRF) model, mean daily temperature, daily maximum temperature, and daily minimum temperature using 9 months of model simulations at 36 and $12 \mathrm{~km}$ resolution, and compared the results with 1182 observational sites in north and central Europe. The quality of the results is then determined in the context of the governing variables used in crop science, forestry, and aerobiological models. We use the results to simulate the peak of the birch pollen season (aerobiology), growth of barley (crop science), and development of the invasive plant pathogen Hymenoscyphus pseudoalbidus (the cause of ash-dieback). The results show that the crop and aerobiological models are particularly sensitive to grid resolution and much higher quality is obtained from the $12 \mathrm{~km}$ simulations compared to $36 \mathrm{~km}$. The results also show that the summer months have a bias, in particular for maximum and minimum temperatures, and that the low/high bias is clustered in two areas: continental and coastal influenced areas. It is suggested that the use of results from meteorological models as an input into biological models needs particular attention in the quality of the modelled surface data as well as the applied land surface modules.
\end{abstract}

\section{Introduction}

Weather models are used for a number of applications such as air quality studies [1-4], weather $[5,6]$, hydrological $[7,8]$ and air pollution forecasting [9-11], crop science [12, 13], and recently also aerobiology [14-16] and ecology [17]. The quality of the data from weather models can have a large impact on the results when they are applied for other purposes such as air quality studies or crop modelling [18-20]. Validation is therefore important in relation to their application and should also include surface meteorological variables (e.g., $2 \mathrm{~m}$ air temperature), which are of wide interest for other applications, like aerobiology, hydrology, and ecology.

One of the most applied weather models is the Weather Research and Forecasting (WRF) model or WRF with chemistry (WRF-Chem) [21, 22]. WRF-Chem is a fully coupled "online" model, in which the air quality component is consistent with the meteorological component in terms of transport scheme, grid definition, time step, and physics $[23,24]$. WRF-Chem allows for feedback between aerosols and meteorology, which again affect the chemical reactions. Recent studies with WRF-Chem have focused on emission input [25-28], planetary boundary layer and surface layer parameterisations [29], chemistry-aerosol mechanisms and sensitivities [30-32], meteorology in relation to atmospheric chemistry $[33,34]$, feedback effects between chemistry and weather $[25,27,35]$, the effect of topography and land use input $[36,37]$, and initial conditions [38]. Other applications of WRF-Chem include studies on wildfires and plume rise [25] or impact of volcanic eruptions on air quality [27, 39]. Validation and sensitivity in relation to the biosphere have however had limited attention in modelling.

The biosphere contains a number of important processes that also interact with both weather and climate. These 
processes include the release of climate dependent gasses, BVOCs [40,41], uptake of $\mathrm{CO}_{2}$ and feedback in the climate system [42], the creation of cloud condensation nuclei [43], and the release of bioaerosols such as pollen, fungal spores, pathogens, virus, and bacteria [44]. The biosphere is usually driven by both seasonal patterns and daily patterns of meteorological conditions $[45,46]$. As an example, the release of bioaerosols from trees is usually during spring, while pollen from grasses and weeds is released during summer or late summer. Finally, pathogens are released from summer to autumn particularly in relation to cropping periods. Pollen is typically released during daytime in periods of dry weather, while the release of some pathogens can be triggered by a decrease in temperature and an increase in humidity. Therefore, the biosphere acts as a source that either directly (pollen) or indirectly (pathogens) releases primary bioaerosols.

The release of primary bioaerosols from trees in relation to human health includes in Europe hazel, birch, oak, alder, olive, and plane [47]. In the USA, the most relevant species include oak, birch, hickory, western red cedar, ash, beech, box, elder, cypress, and maple [48], for example, Asthma \& Allergy Foundation of America: http://www.aafa.org/. Both groups of trees are important as a source of biogenic volatile organic compounds (BVOCs) $[40,49]$ and their pollen is known to cause substantial allergic reactions $[50,51]$. The governing parameters for the seasonal and daily release of bioaerosols from these tree species are mainly daily mean, daily maximum, and daily minimum temperatures [52], as well as the heat accumulation (degree day/hour) during or before the season [53-56].

Bioaerosols are also released from crop systems. The main crops from the Poaceae family in both Europe and USA include wheat, barley, and rye $[19,57]$. These crops are important in relation to the atmospheric nitrogen budget [41] and they act as a host for important pathogens during crop growth that may be released passively or during harvesting [58]. The governing parameters for the growth of these crops in the main agricultural regions are usually water, nutrients, and temperature [19].

Pathogens occur on many annual and perennial agricultural crops [59] and trees [60,61]. Important pathogens in crops include Phytophthora infestans, Puccinia hordei, and Botrytis cinerea, which are responsible for extensive losses in potatoes and cereals. On trees, important pathogens include Ganoderma spp., Phytophthora ramorum, and Hymenoscyphus pseudoalbidus causing diseases such as sudden oak death and ash-dieback. Some naturalized pathogens like Alternaria, Didymella, and Ganoderma can affect human health [6264] and have a substantial negative economic impact [59]. Other pathogens, such as Hymenoscyphus pseudoalbidus, are considered invasive and are currently spreading throughout Europe [65]. Many approaches have been used to determine the actual development time of plant pathogens. The governing parameters for the growth of these pathogens are usually water (humidity) and temperature [66], which is typically simulated with growing degree days or growing degree hours [67] or regression models [68]. Such data are often obtained from atmospheric models like WRF or WRF-Chem.
The application of atmospheric models should focus on the quality of the governing variables in relation to their application. Governing variables in relation to the biosphere and bioaerosols are temperature and temperature variations on both a daily and seasonal scale. The purpose of this study is to investigate the quality of the most relevant parameters in relation to the simulation of relevant processes in the biosphere, such as crop growth, release of pollen during spring, and growth of pathogens. This will be done by making a traditional statistical evaluation of surface temperatures simulated by WRF (WRF-Chem without the aerosol feedback) and also by applying typical models for crop growth (spring barley), the pollen season (start of birch pollen), and pathogen growth (in vitro: ash-dieback).

\section{Data and Methods}

2.1. Observations. Surface meteorology was obtained from the global surface summary of day data (GSOD) that is exchanged under the World Meteorological Organization (WMO) World Weather Watch Program. This data set included 1919 sites within the investigated area with daily values of maximum, minimum, and mean temperatures for the year 2012. These data have been put into three groups, where the first two are used for different tasks in the evaluation: (a) sites with records every day and where each daily record is based on minimum of $75 \%$ of all hourly records (Figure 1); (b) sites with daily records for $75 \%$ of the year and where each daily record is based on a minimum of $75 \%$ of all hourly records (Figure 1); and (c) sites with records below the $75 \%$ threshold.

2.2. Model Simulations. Model calculations were made with the WRF-Chem model [69] version 3.5 using two domains in the application of WRF [21]. The main setups and input data used in the study are provided in this section. Initial and boundary meteorological conditions are based on the FNL (Final) global analysis data. FNL are created and maintained by the National Centre for Environmental Predictions (NCEP) having a spatial resolution of $1^{\circ} \times 1^{\circ}$ (longitude-latitude), a temporal coverage of 6 hours, and a vertical resolution of 27 pressure levels. Each new FNL data set is nudged into WRF-Chem and output and restart files are created for every day. The model was run with two two-way nested domains, where domain 1 (36 km grid resolution) covers all of Europe, parts of Asia, the Atlantic, and Africa (Figure S1; see Supplementary Material available online at http://dx.doi.org/10.1155/2015/412658), while domain $2(12 \mathrm{~km})$ covers central Europe and parts of southern and northern Europe (Figure 1). Feedback between chemistry, aerosols, and meteorology was turned off to focus on the impact of the physics in WRF-Chem on the meteorological results. The functionality is therefore as close as possible to WRF and we therefore use the WRF name in the following parts of the paper. A companion paper describes the chemistry part and in particular the setup and results that are obtained with a new climate dependent emission model for ammonia [70]. The following physics options were applied for the simulation: rapid radiative transfer model (RRTM) 


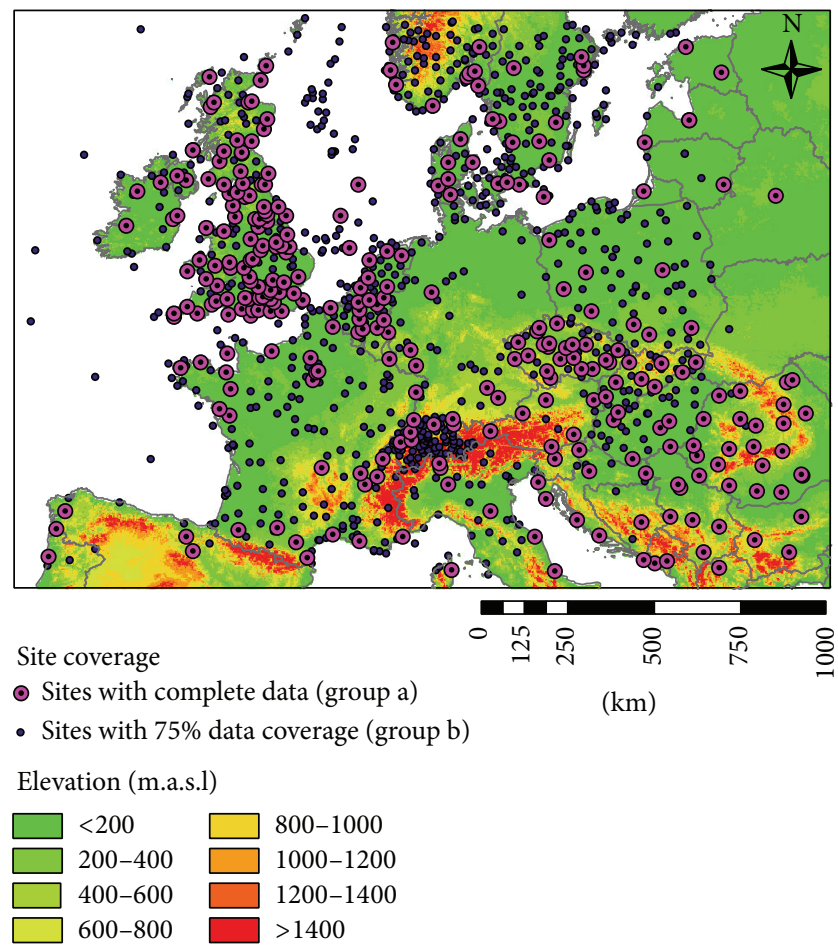

FIGURE 1: Study area and location of stations according to the selection criteria.

for longwave radiation [71], Dudhia scheme for shortwave radiation [72], MYNN PBL scheme [73], NOAH land-surface model [74], and a modified version of the Kain Fritsch Scheme for the cumulus parameterisation [75]. The standard setup of a vertical structure of the planetary boundary layer (PBL) in WRF was modified to obtain better information to study emission and dispersion of bioaerosols near the surface. The total number of layers was increased from 27 to 48 and the increased number of layers concerns the first 1015 meters.

\subsection{Statistical Evaluation and the Application of Growth} Models for Sensitivity Studies. The statistical evaluation of the model results was carried out using results from both domain 1 and domain 2 over the geographical area that is covered by domain 2 . The statistical evaluation was carried out for mean (Tmean), minimum (Tmin), and maximum (Tmax) air temperature using all sites from group (b). Model performance at each site was evaluated using bias and daily fluctuations by correlation coefficients and root mean squared error (RMSE). Bias for each site for the three first quarters (Q1: January-March, Q2: April-June, and Q3: July-September) was displayed on a map for both model domains (Figures 2(a)-2(f)). Similar figures for maximum and minimum temperatures are available in Supplementary Material (Figures S2 and S3). The correlation for each site for the three first quarters was displayed on a map for both model domains (Figures 3(a)-3(f)). The maps are then analysed using local Moran's I statistics [76] in order to explore a tendency of spatial clustering of high or low values of bias and correlation coefficient for each season and separately for two model domains. The tool also allows identification of spatial outliers, for example, low/high bias surrounded primarily by high/low values of bias, and to assess the statistical significance of clustering.

Finally, overall evaluation for the entire model domain was carried out using scatter plots for each quarter of the year (Figure 4) using correlation coefficient $(R)$ and root mean squared error. This calculation of the domain-wide error statistics is a traditional procedure used in both air quality and meteorological studies to verify the performance of different models, for example, [77, 78]. However, this domain-wide approach may also cover some local issues related with the model performance, because for certain areas the model may behave in a different way than suggested by the global error statistics. To take this into account in this study this traditional domain-wide approach is complemented with the spatial assessment using Moran's statistics, to quantify the model tendencies for grouping of high or low values of error statistics. Simulation of the growth of spring barley (Figures 5(a) and 5(d)), the peak of the birch season (Figures 5 (b) and 5(e)), and the growth of the pathogen causing ashdieback (Hymenoscyphus pseudoalbidus) (Figures 5(c) and 5(f)) was carried out for both domains using sites from group (a), thus only the sites with a full data record. A trendline is shown for each of these scatter plots with the determination coefficient $\left(R^{2}\right)$. The peak of the birch season is based on accumulation of growing degree days since 01 January (Appendices A, B, and C) as temperature is the main parameter that governs flowering $[55,79]$ and the growth of spring barley on accumulation of growing degree days (GDD) since $01 \mathrm{March}$, which is expected to work well for central-northern Europe [19] (Appendices A, B, and C). 


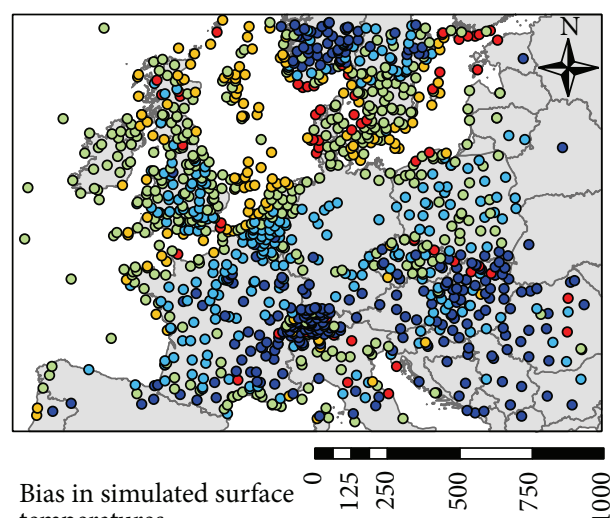
temperatures

$$
\begin{aligned}
& \text { ○ }-2.0--1.0 \quad \bigcirc>2.0 \\
& \text { ○ }-1.0-1.0
\end{aligned}
$$

(a)

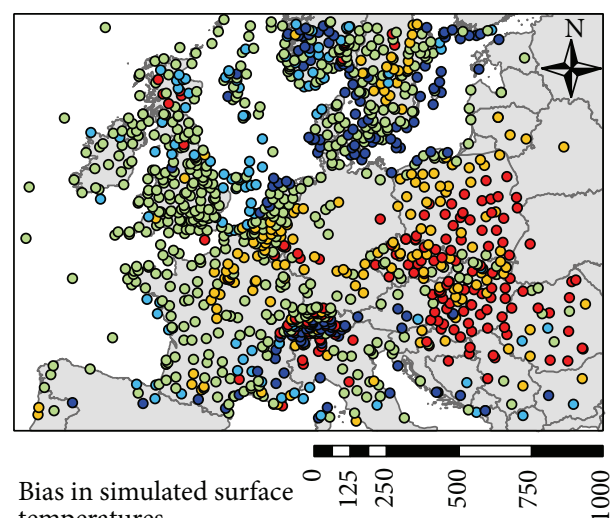
temperatures

$$
\begin{aligned}
& 0<-2.0 \\
& \text { ○ 1.0-2.0 } \\
& \text { ○ }-2.0--1.0 \\
& \text { ○ - } 1.0-1.0
\end{aligned}
$$

(b)

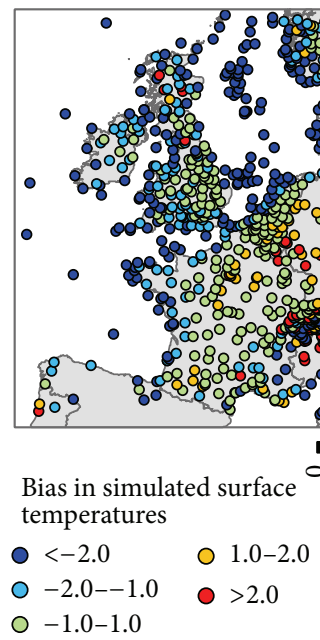

(c)

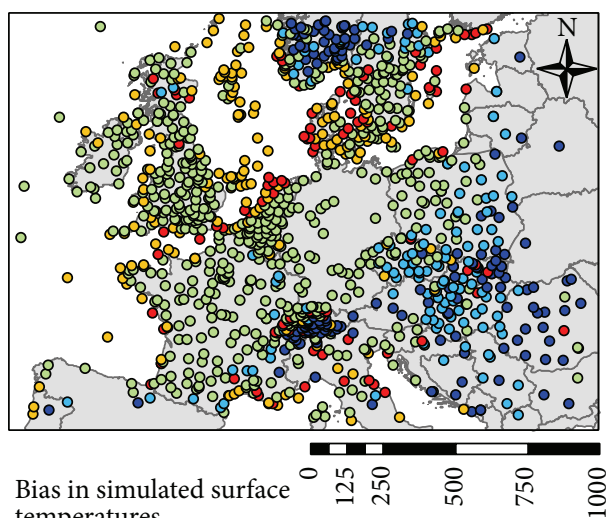

temperatures

$$
\begin{array}{ll}
\circ<-2.0 & \circ 1.0-2.0 \\
\bigcirc-2.0--1.0 & \bigcirc>2.0 \\
0-1.0-1.0 &
\end{array}
$$

(d)

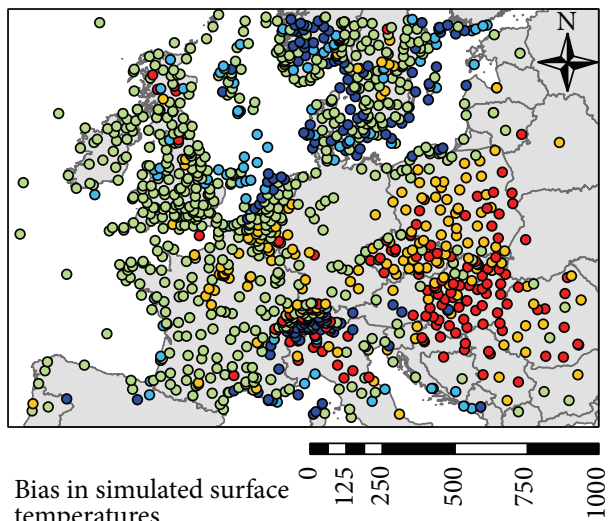
temperatures

$$
\begin{array}{ll}
0<-2.0 & \circ 1.0-2.0 \\
\bigcirc-2.0--1.0 & \bigcirc>2.0 \\
0-1.0-1.0 &
\end{array}
$$

(km)

(e)

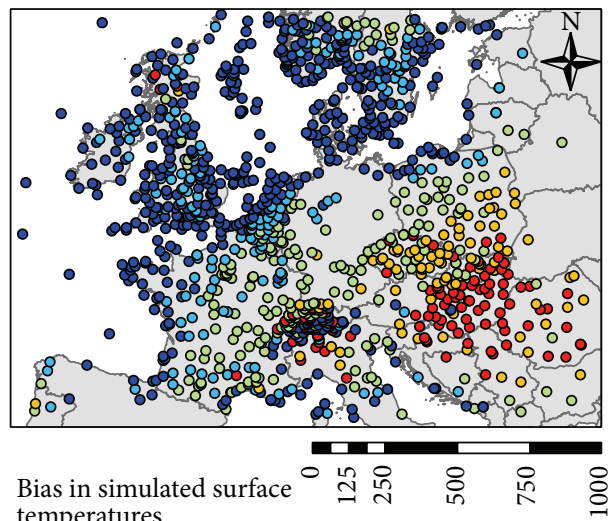

$$
\begin{array}{lll}
\circ & -2.0--1.0 & \circ \\
0 & -1.0-1.0 &
\end{array}
$$

(km)

(f)

FiguRE 2: Simulation of daily mean temperatures for Q1 ((a) and (d)), Q2 ((b) and (e)), and Q3 ((c) and (f)) at 1182 sites in central-northern Europe. First column corresponds to WRF-Chem simulations with $36 \mathrm{~km}$ resolution and second column to WRF-Chem simulations with $12 \mathrm{~km}$ resolution. 


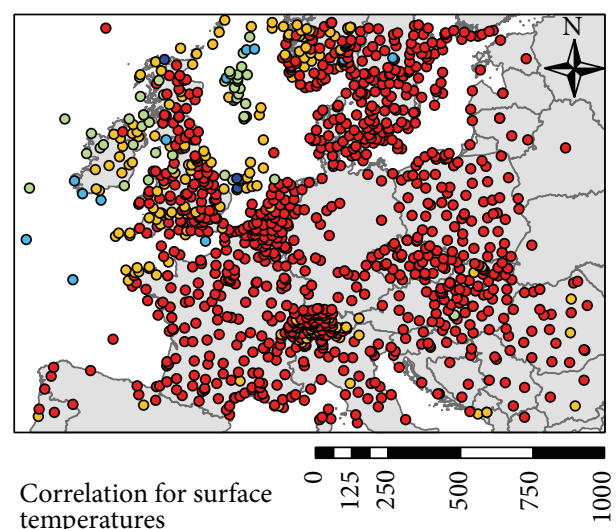
(1)

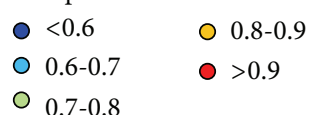

(a)

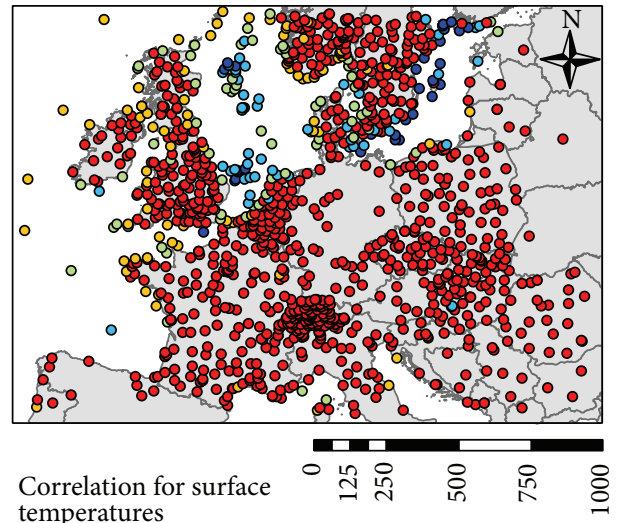

$\begin{array}{llll}\circ<0.6 & & 0.8-0.9 & (\mathrm{~km}) \\ \bigcirc & 0.6-0.7 & & \end{array}$

(b)

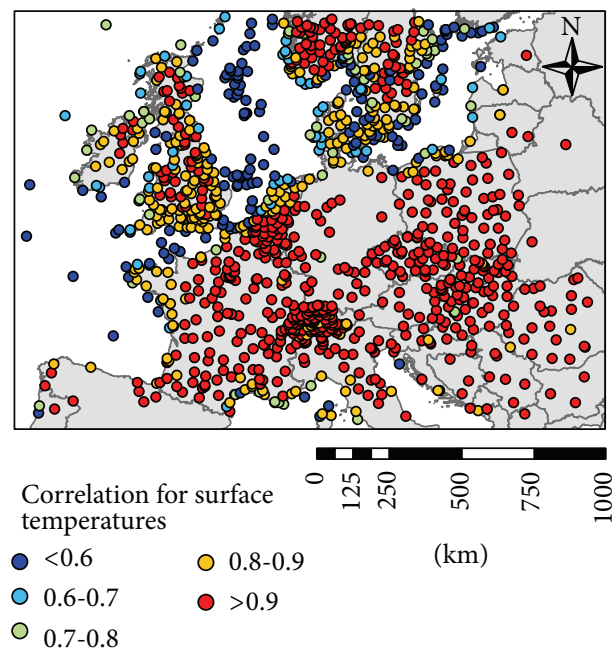

(c)

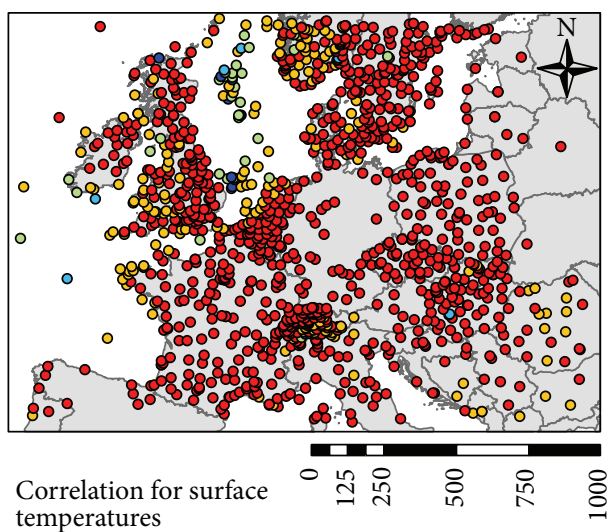

○ $<0.6$ o $0.8-0.9$

(km)

○ $0.6-0.7 \quad 0>0.9$

O $0.7-0.8$

(d)

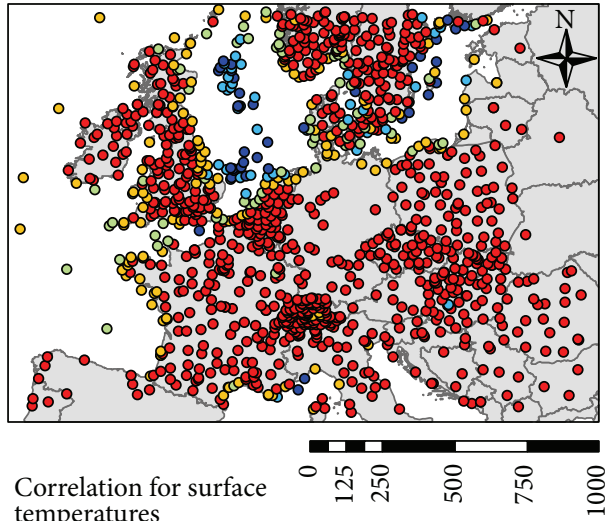
o $<0.6$
○ $0.8-0.9$
$(\mathrm{km})$
○ $0.6-0.7$
○ $>0.9$
○ $0.7-0.8$

(e)

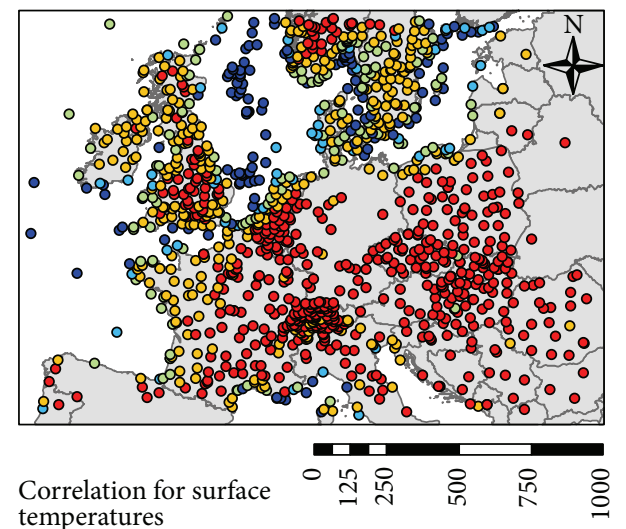
○ $<0.6$
○ $0.8-0.9$
○ $0.6-0.7$
○ $0.7-0.8$
○ $>0.9$

$(\mathrm{km})$

(f)

FIGURE 3: Correlation between simulation and observed daily mean temperatures for Q1 ((a) and (d)), Q2 ((b) and (e)), and Q3 ((c) and (f)) at 1182 sites in central-northern Europe. First column corresponds to WRF-Chem simulations with $36 \mathrm{~km}$ resolution and second column to WRF-Chem simulations with $12 \mathrm{~km}$ resolution. 

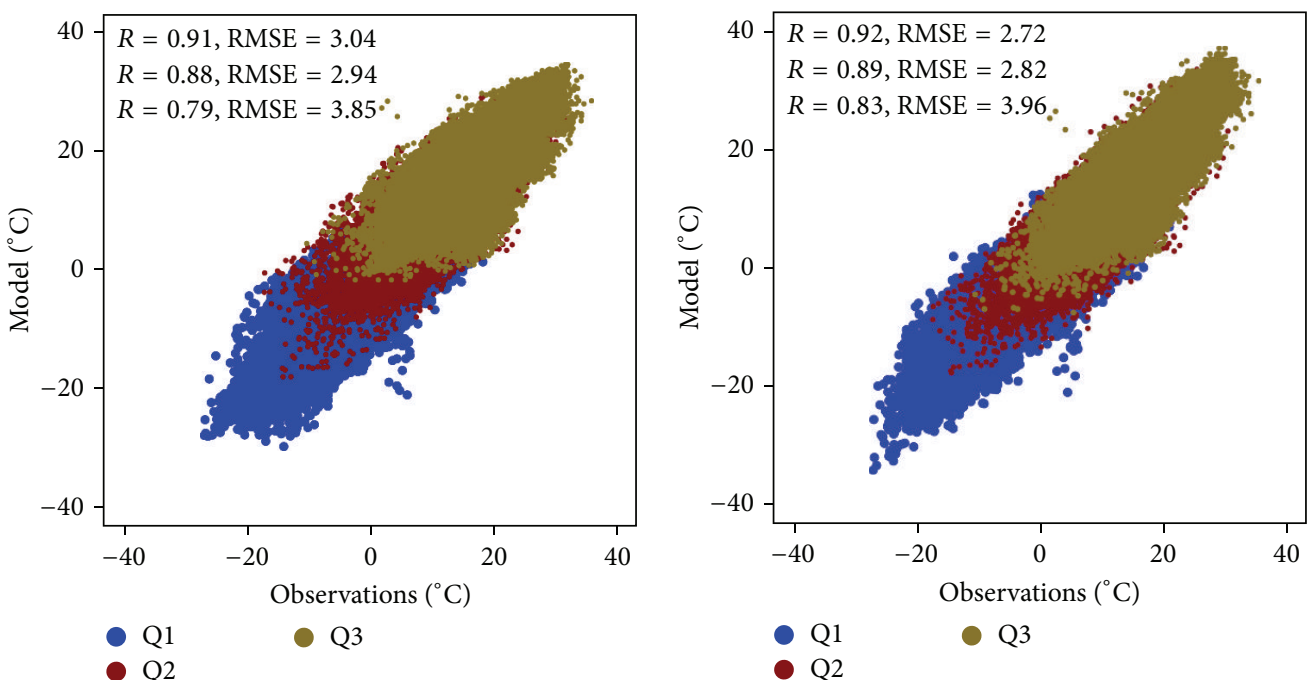

(a)
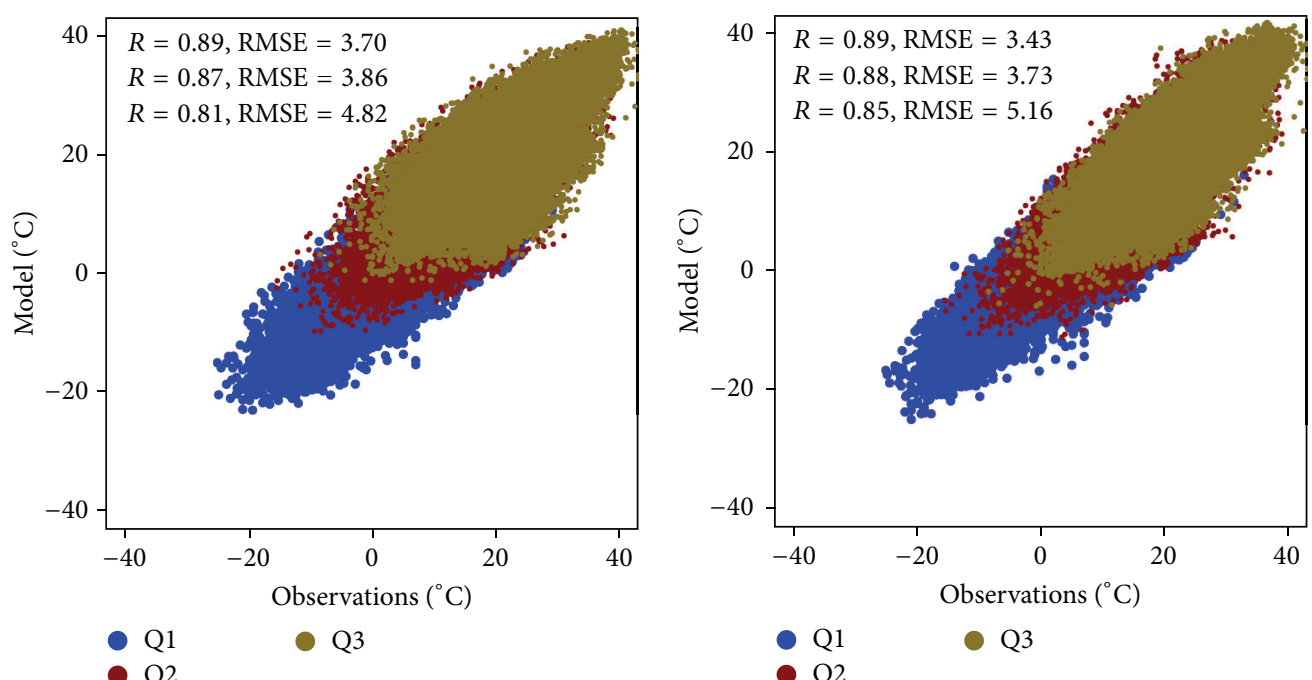

(b)
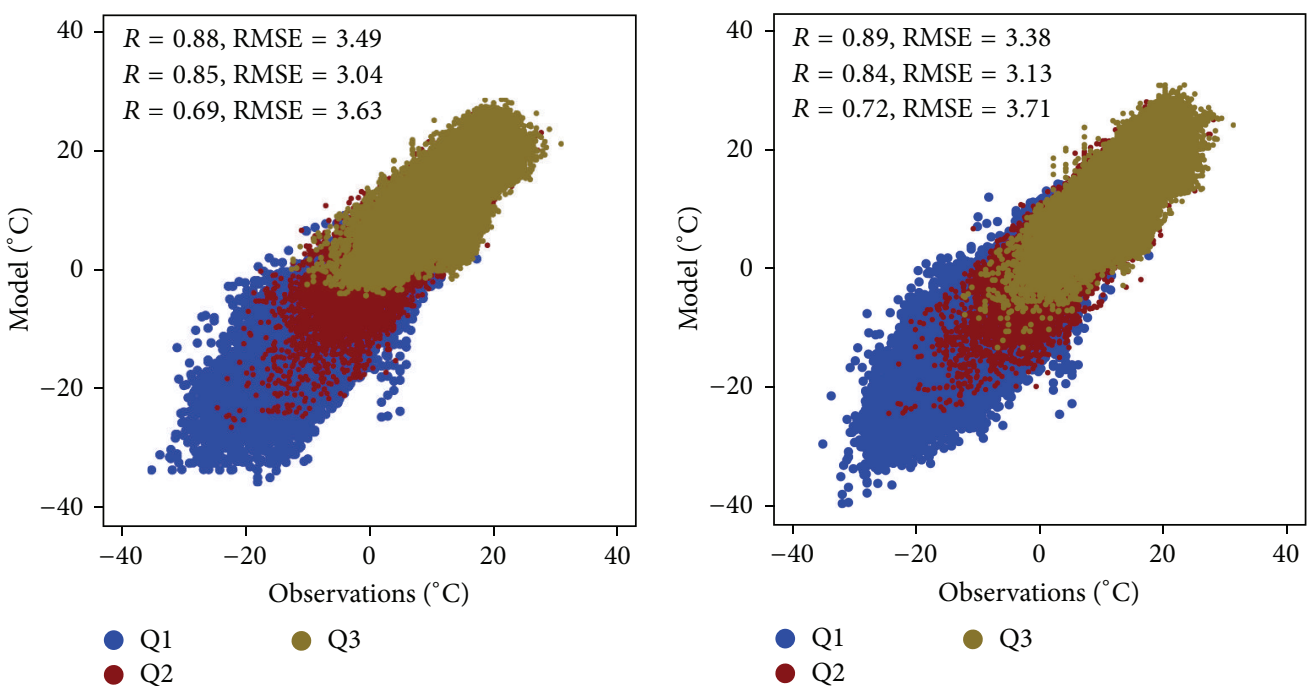

(c)

(f)

FIGURE 4: Simulation of daily mean ((a) and (d)), daily max ((b) and (e)), and daily minimum temperatures ((c) and (f)) using WRF-Chem. First column corresponds to WRF-Chem simulations with $36 \mathrm{~km}$ resolution and second column to WRF-Chem simulations with $12 \mathrm{~km}$ resolution. 


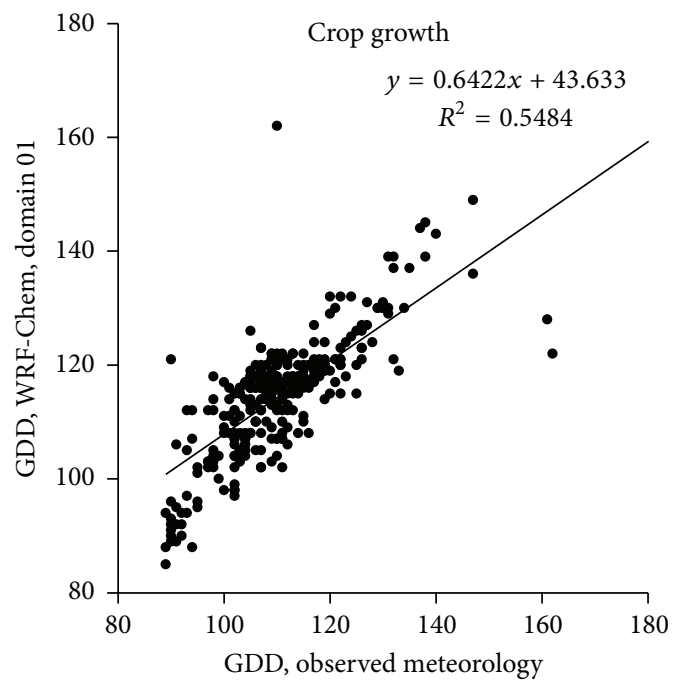

(a)

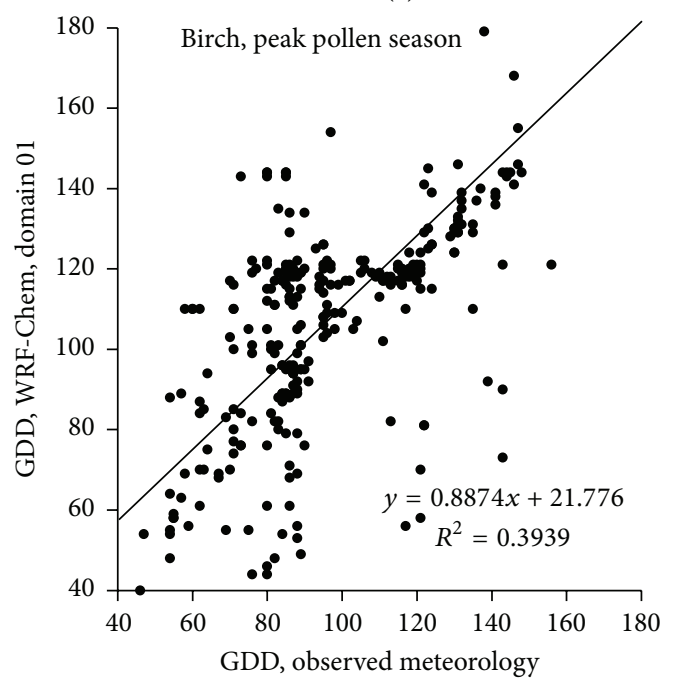

(b)

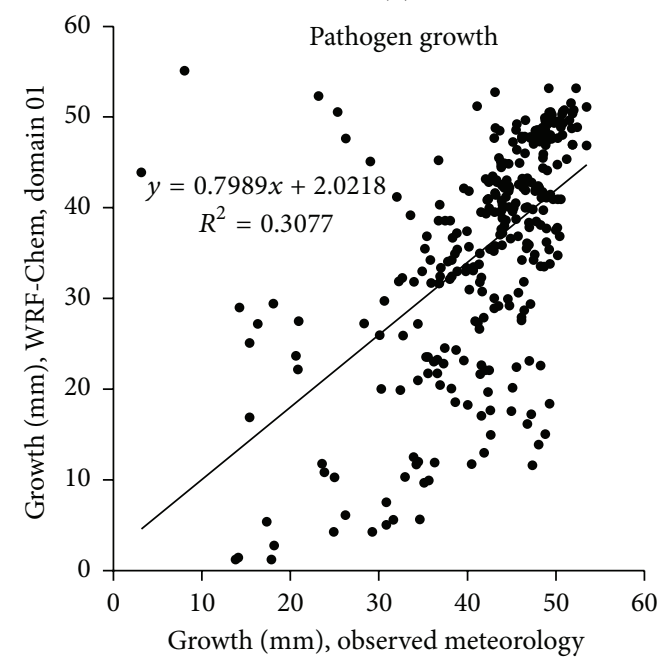

(c)

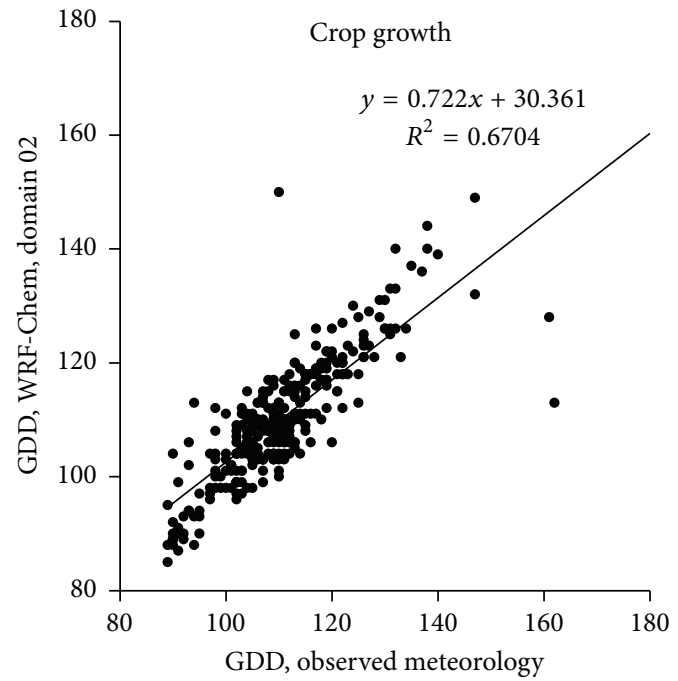

(d)

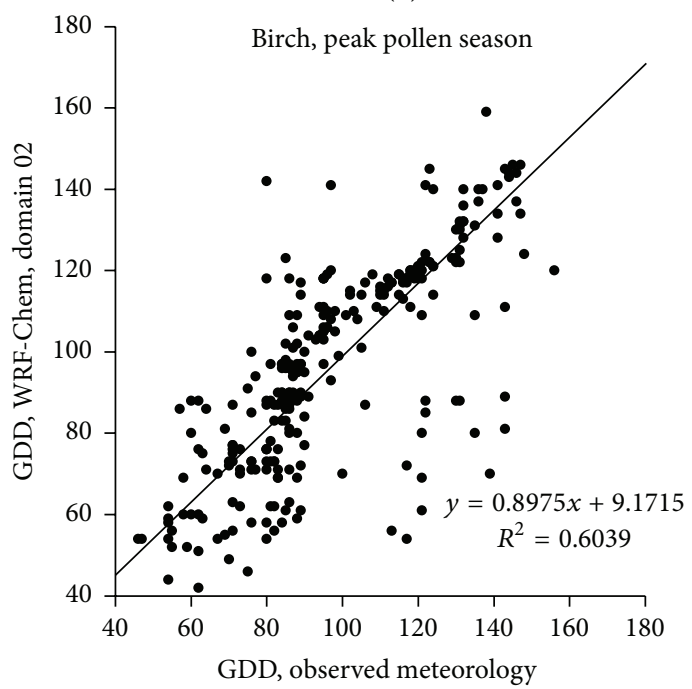

(e)

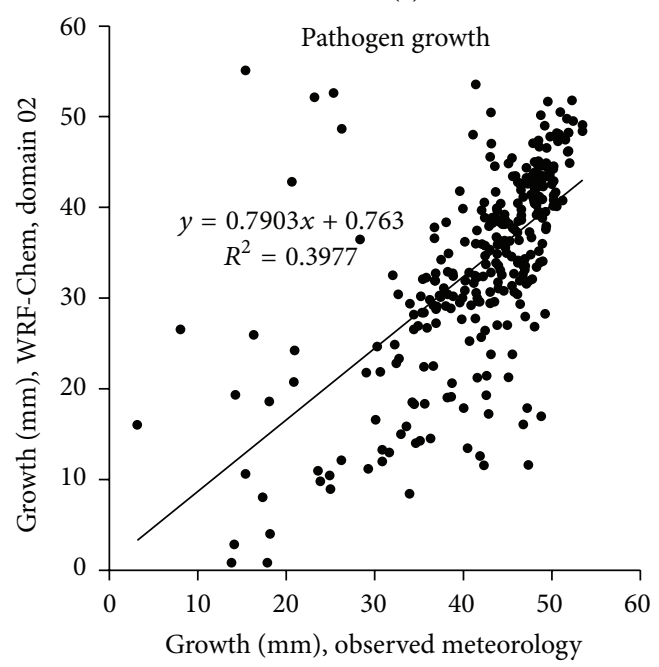

(f)

FIGURE 5: Simulation of crop growth ((a) and (d)), pollen season ((b) and (e)), and pathogen growth ((c) and (f)) using observations and model results at selected sites in central-northern Europe. First column corresponds to WRF-Chem simulations with $36 \mathrm{~km}$ resolution and second column to WRF-Chem simulations with $12 \mathrm{~km}$ resolution. 
The predicted growth of the pathogen uses a parametrised growth function (Appendices A, B, and C) which was derived from published laboratory experiments and then applied to simulate the main growing season (July) that eventually leads to sporulation, usually in late July and August [65].

\section{Results}

3.1. Geospatial Validation of Tmean, Tmax, and Tmin. The observational data from group (b) provided 1182 sites that were suitable for geospatial validation (Figure 1). The bias in mean surface temperature between the WRF calculations and GSOD data is unevenly distributed over both model domains for Q1, Q2, and Q3 (Figure 2). Spatial distribution of bias and correlation coefficient (Figure 3 ) is in general similar for Tmean, Tmax and Tmin. Outliers, in terms of local Moran's index, are usually found for mountainous stations. Bias is statistically significantly clustered, according to the local Moran's $I$ index, along coastal areas and in mountain regions and this bias and clustering is usually smaller in domain 2 compared to domain 1 (Figure 2).

For the Q1 and the Q2 simulations, the number of sites with small bias ( -1 to 1 degree) is higher in domain 2 and mainly located in France, the British Isles, Benelux countries, and Denmark. For Q1, there is a statistically significant tendency for clustering of low values of bias and high correlation coefficient in eastern and SE Europe. The clustering in this case is stronger for domain 2. Domain 2 has higher positive bias along the coast if compared to domain 1 (e.g., for France, Belgium, United Kingdom, and Netherlands), especially for Tmin.

For Q2 and Q3 there is a bias above 2 degrees in Tmean over Poland and the Carpathian Basin and for Q3 a similar negative bias in the regions near the North Sea. Local Moran's index shows a statistically significant tendency for clustering of high values over eastern Europe, and the bias is smaller (in terms of absolute values) for domain 2, if compared to domain 1. Coastal stations are underestimated, and the tendency for clustering of low bias is statistically significant along the shorelines, for example, Belgium, Netherlands, and Scandinavia. Overall the best results in the domain-wide statistics with highest correlations and smallest RMSE are for Q1 and Q2, with a general increase in correlation going from domain 1 to domain 2 (Figure 4). There is a decrease in bias in Q1 and Q2 for maximum temperature and an increase in bias in Q3 is seen with the increased resolution from domain 1 to domain 2. Overall there is a lower correlation on maximum temperatures compared to mean temperatures (Figures 4(b) and $4(\mathrm{e})$ ), but still the correlation increases from domain 1 to domain 2, but on Q3 the RMSE increases from domain 1 to domain 2. For minimum temperatures and the spatial pattern (Figure S3), there is a large positive bias at most coastal sites during Q1 and a small to medium bias at most other sites. In Q2 there is limited bias in the western part of the domain and a bias above 2 degrees in the eastern part of the domain. In Q3 there is a large negative bias (below 2 degrees) at most sites near coastal regions and a large positive bias over Poland and the Carpathian Basin. Overall the correlation increases when going from domain 1 to domain 2 (Figure 4). For Tmax and Tmin, statistically significant clustering of high values is observed in eastern Europe.

The correlation on daily mean temperatures is displayed spatially in Figure 3, which shows that the correlation for most sites is above 0.9. Sites with lower correlations are located near coastal areas, especially in Scandinavia or in mountain regions, where the local Moran's I index shows statistically significant tendencies for clustering of low values. Similar spatial pattern is found for Tmin and Tmax. In Q2 and Q3 correlation coefficient shows statistically significant clustering of high values for Tmean in central France, south Germany, the Czech Republic, Austria, and south Poland for both domain 1 and domain 2. The simulation for Q3 had a larger number of sites with correlations between 0.8 and 0.9 and this number is larger in domain 2 compared to domain 1 (Figures 3(c) and 3(f)). The spatial correlations on both maximum and minimum temperatures (Figures S4 and S5) have a smaller number of sites with correlations above 0.9 compared to daily mean temperatures (Figure 3). The simulations with smallest correlations are for Q3 for both maximum and minimum temperatures. Additionally, the number of sites with correlations smaller than 0.9 is larger in domain 2 compared to domain 1 (Figures S4c, f and S5c, f).

3.2. Sensitivity Study on the Application of Surface Temperatures on Vegetation Modelling. The observational sites from group (a) provided 307 sites that were suitable for the sensitivity studies on vegetation modelling (Figure 1). The scatter plots (Figure 5) show that the structure of the vegetation models caused a difference in the uncertainty, when compared with observations. The smallest sensitivity is seen for crop growth models using the GDD method, followed by modelling of the pollen season for trees, and the largest sensitivity is seen for pathogen growth. An increase in model grid resolutions from $36 \mathrm{~km}$ to $12 \mathrm{~km}$ affects the model results substantially causing an increase in correlation from 0.74 (crop), 0.63 (tree pollen), and 0.55 (pathogen) to 0.82 (crop), 0.78 (tree pollen), and 0.63 (pathogen), respectively. Similarly, the bias is changed from 4.06 days (crop), 11.12 days (tree pollen), and $-6.41 \mathrm{~mm}$ (pathogen) to -0.39 days (crop), -0.52 days (tree pollen), and $-8.03 \mathrm{~mm}$ (pathogen), respectively.

\section{Discussion}

4.1. Discussion of the Geospatial Variations in Tmean, Tmax, and Tmin. The geospatial investigation of results from the WRF model shows that the Tmean, Tmax, and Tmin bias can be substantial, in particular near mountain and coastal areas. The results show an opposite seasonal cycle in bias observed for western (maritime) and eastern (continental) Europe. The results also show a spatial pattern at the observational sites. The pattern shows that sites were clustered in terms of similar bias and correlation coefficient, where this grouping is statistically significant according to the local Moran's index. This suggests that there are some regional tendencies for either under- or overestimation of Tmean, Tmax, and Tmin. The quality of the model results therefore varies from one geographical area to the other. This spatial pattern in 
the quality of modelled variables is important in terms of further applicability of these meteorological data from the WRF model. The best results are obtained in areas that are influenced by a maritime climate (e.g., UK, parts of France, and Germany) during Q1 and Q2 and the results are better from domain 2 compared to domain 1. During Q3 the results are inferior compared to Q1 and Q2 and the improved resolution in domain 2 has not caused an increase in the quality of the model results. Overall, domain 2 has a limited bias in mean temperature in Q3. However, the results clearly show that there is a statistically significant clustering of a positive bias over continental areas like Poland and a negative bias over areas with maritime influence like the UK. This clustering in bias is visible for Tmean, Tmax, and Tmin and it shows that a spatial evaluation is always needed for this kind of study. Similar results have been reported in long term studies for Poland [80] or for Europe by Katragkou et al. [81]. Over Europe, Katragkou et al. used WRF ensemble data to show systematic biases in air temperature and rainfall and they suggested that different physical mechanisms are responsible for these biases that are observed during the summer and winter seasons. Our study supports these findings by showing spatial grouping of the data with large differences between seasons and between maritime climate and continental climate.

4.2. Variations in Tmean, Tmax, and Tmin at Different Spatial Resolutions in WRF. The prediction of Tmax is improved with increasing resolution during both Q1 and Q2. However, the prediction of Tmax shows a substantial bias in Q3 throughout most of the model domain. Similar patterns in improvements in bias are seen for Tmin as well as for the correlation coefficient. These results suggest that the governing processes in relation to surface temperatures are only partly related to grid resolution, elevation, and land-sea interactions. For both model resolutions there is a low correlation and substantial bias at some seashore stations. This is due to the fact that this particular grid cell in the WRF model is represented by sea-surface, while the station is located at land. With increased resolution, this uncertainty becomes less important. With higher resolution other processes that relate to the chosen land model, PBL, or surface layer parameterisations become increasingly important compared to the land-sea uncertainties. Finally, a large bias at sea areas, such as the central North Sea, could be explained by a lack of accuracy in the daily SST input data. This inaccuracy over sea-surfaces is unlikely to have a direct impact on the application of the data from WRF on vegetation models. The uncertainty over the North Sea is expected to mainly influence the coastal zones. Similar findings to this study were presented earlier, for example, by Mooney et al. [82], who had shown large biases in WRF modelled air temperatures (up to $4 \mathrm{~K}$ ). Mooney et al. [82] attributed these uncertainties mainly to land surface models and, to a lesser extent, to selected radiation schemes, microphysics, and planetary boundary layer schemes. Furthermore, Soares et al. [83] showed that increasing model resolution over Portugal has reduced the biases in air temperatures (including minimum and maximum temperatures) for the areas of more complex terrain. The higher grid resolution in this study resulted in a reduction of large regional biases over Norway in a similar way as reported by Heikkila et al. [84]. These previous findings agree well with the findings in this study. An overall conclusion is that when the data are used for vegetation models, the atmospheric models should have sufficiently high spatial resolution and there needs to be a focus on the applied land surface models.

4.3. Comparison against Related Studies with WRF and WRF-Chem. Recently the Air Quality Modelling Initiative (AQMEII) [85] also found high daily and seasonal correlations of temperature but a negative bias in Tmax in WRFChem results $[33,86]$. The AQMEII focused on simulations over Europe and North America for the year 2010. These results were obtained with a $24 \mathrm{~km}$ grid resolution, the same land surface scheme as in this study but a different PBL scheme over Europe. Here we use the MYNN PBL scheme [73] compared to the YSU [87] scheme in AQMEII studies over Europe. The AQMEII simulations over North America as well as in this study use the MYNN PBL scheme and associated surface layer scheme, as this has shown to provide better results in mid-latitudes in USA [88] with grid resolutions in the range of $12-4 \mathrm{~km}$. Our study also has a higher number of vertical layers in WRF (48 versus 33) for improved description of near-surface energy fluxes. Despite these changes, both sets of model simulations suggest underestimation of summer and late summer maximum temperatures and that an increase in model resolution or number of vertical layers does not solve this problem, and neither do the differences in PBL parameterisations. Instead, a likely solution could be more focused on the land surface models as suggested by Mooney et al. [82]. Studies on primary biological aerosols, such as pollen or fungal spores, have suggested that micro-, meso-gamma and mesobeta are the governing spatial scales for their dispersion [89-91], as defined by Orlanski [92]. Contrarily, the wellstudied long distance transport episodes are irregular and episodic phenomena $[93,94]$. In relation to this, a study over the Iberian Peninsula [20] on the transport of pollen showed that the application of WRF results with $9 \mathrm{~km}$ grid resolution provided a substantial improvement compared to WRF results with a $27 \mathrm{~km}$ grid resolution. The same study also showed that a further increase to $3 \mathrm{~km}$ resolution only provided small changes. These previous results, as well as the results in this paper, suggest that the application of WRF results, in relation to vegetation studies and the dispersal of gases and particles from the vegetation, is sensitive to the chosen grid resolution. This study shows by the application of different vegetation models that the grid resolutions must cover the meso-beta scale well (e.g., at least $9-12 \mathrm{~km}$ grid resolution). It also shows that the governing parameters that drive the vegetation fluxes (e.g., Tmean, Tmax, and Tmin) must be carefully evaluated in relation to their application, which includes focus on the applied land surface models.

4.4. Use of Gridded Temperature from WRF and Other Numerical Models for the Simulation of Phenology. The application 
of the different biological growth models focuses on the phenology of selected taxa during early spring (tree pollen), late spring (crop growth), and mid-summer (pathogen growth). Vegetation is, in general, sensitive to temperature and a systematic bias in the range $1-2 \mathrm{~K}$ can cause substantial change in the behaviour of dynamic vegetation models without a bias correction [95]. A good example is that an increase in elevation of 300 meters will as a rule of thumb cause a decrease in air temperature of $1.95 \mathrm{~K}$, because the mean environmental lapse rate is $0.65 \mathrm{~K} / 100$ meters. A study by Ziello et al. [96] from the Alpine region showed that a change in elevation of $300 \mathrm{~m}$ will cause a shift in phenology from 9 to 14 days for 6 out of 10 investigated species. Vegetation models are able to take such impacts of temperature into account. A bias in temperature therefore has a large impact on well calibrated vegetation models. These integrated effects from temperature and a bias in model results will impact both the phenology and the vegetation composition [95]. The effects may also affect certain triggers of events that cause BVOC release during flowering [97], the intensity of the daily flowering process from trees $[98,99]$, weeds [100], and grasses [101], or growth and release of pathogens in either crops [68] or trees $[65,66]$.

4.4.1. Impact of Grid Resolution on Phenological Models for Grass and Trees (Birch). The sensitivity study (Figure 5) shows that the bias as well as the generally lower correlation of the 2-meter temperature from domain 1 has a substantial impact on the vegetation modelling (Figures 5(a) and 5(b)) and the simple increase in grid resolutions has a large positive effect on the model calculations (Figures 5(d) and 5(e)). The major cause of this is that vegetation models generally base the phenological development on the accumulation of heat, which in this case is expressed as growing degree days. Here the increase in grid resolution (domain 1 to domain 2) decreased the systematic bias from 4 and 11 days to less than 1 day (Figure 5) for crop growth and the peak of the birch pollen season. This increase in the quality is obtained mainly from the decrease in bias during Q1 in domain 2 (Figure 2(d)) and part of the domain in Q2 (Figure 2(e)), while the bias in the temperatures seen in Q3 will not affect these models. However, this increase in quality is only with respect to overall statistics. There are still a large number of outliers (e.g., Figures 5(d) and 5(e)) which are caused by a bias. Figure 2 shows that there is a minimum bias in the UK and France, while Spain, Italy, Poland, Hungary, and the Baltic countries are having a large bias. A consequence is that the phenological models for crop growth and birch flowering will have the highest quality in the UK and France and we can expect uncertainties of 10 days or more in areas like the Baltic countries and parts of eastern and southern Europe. This therefore highlights the importance for spatial evaluation of the models results. This result corresponds very well with a recent study on birch pollen simulations from the MACC consortium [102]. They studied the 2013 season and used pollen data from 12 countries. They found very good agreement between model results and observations with respect to the season start in Germany and France and errors of 10 days or more in areas like Spain, Portugal, the Baltic countries and Finland. Sofiev et al. [102] attribute their errors to be due to two terms: missing interannual variability of the pollen production and errors in mountainous regions. However many of the errors are located in less complex terrain such as the Baltic countries and the large plateaus on the Iberian Peninsula, so it is less likely that complex terrain is the cause of some of the uncertainties. Our results show that a systematic bias in temperature that is found in WRF matches the areas with large uncertainties found in the MACC Ensemble. It is however not known if the uncertainty in the MACC Ensemble is due to a bias in surface temperature as this aspect was not covered in their study. However, the combined results and the fact that numerical weather prediction models in general contain a bias allow us to presume that bias in surface temperatures will contribute to model errors both in our case and in the MACC Ensemble.

4.4.2. Impact of Grid Resolution on Models for Pathogens. The model for pathogen growth showed little improvement with the increased resolution and in general there was much lower quality in the results from this model compared to the model for grass and birch. This was caused by substantial biases in domain 2 during Q3. Unfortunately, the bias is present exactly within the temperature area where the pathogen model is most sensitive: $25-35^{\circ} \mathrm{C}$. Therefore, despite a relatively low overall bias during Q3, the actual spatial uncertainty of the model results (positive over continental areas and negative over marine influence areas) causes much lower results on vegetation modelling during this period. Similarly, a systematic bias will also cause additional uncertainty in climate sensitive gasses such as isoprene from trees [40] or ammonia from agriculture [41, 103]. In general these gasses are climate dependent and the majority of the emissions from their sources occur between spring and autumn.

4.4.3. Use of Vegetation Models in relation to WRF. The applied models might be considered too simple. Pathogen models often include combinations of temperature and wetness [68] and many woody plants need to complete vernalisation before accumulation of heat is activated [104]. Overall, this shows that the development of dynamic vegetation models into on-line models like WRF is a complex issue in a similar way to the chemistry part in WRF-Chem. A number of feedback processes in WRF-Chem (e.g., isoprene or ammonia release causing aerosols) affect the results of meteorological parameters. Other vegetation processes are very sensitive to both small errors and bias, where the release of primary biological aerosols (e.g., pollen, fungal spores, and bacteria) is prominent example of very sensitive emission processes. Currently the simulations of the tree pollen season and crop growth appear to behave well in central parts of the model domain if the grid resolution in WRF is sufficiently high. However there are unresolved issues in coastal regions and areas like the Iberian Peninsula and the Carpathian Basin. The simulation of pathogens clearly needs further improvements. WRF also shows a substantial dependency on land use and the details in topography in the calculation of temperature and wind speed [36]. As shown in this study, uncertainties in these variables cause considerable 
uncertainty in vegetation models, since errors tend to accumulate over time. Therefore, this needs to be solved for some applications (e.g., as in the example on a pathogen model). In the short term, the best approach to get better surface data is probably postprocessing of the data through bias correction [96] or to include data assimilation of the surface data. In the long term, it is however clear that if atmospheric models should be used on a range of vegetation studies, then the model needs a direct implementation of relevant biological processes. Such an implementation needs attention on both the applied surface data (e.g., land cover data and vegetation data at the species level) and the parameterisations (e.g., land surface models) that apply to these data.

\section{Conclusion}

The quality of the three governing parameters Tmean, Tmax, and Tmin as simulated by WRF is here assessed statistically in north and central Europe. The results show that the spring period is better simulated than the summer period, where there is a tendency to underestimate high temperatures and daily maximum temperatures. The model results are improved during the first two quarters of the year, when the grid resolution is increased (from 36 to $12 \mathrm{~km}$ ), but on the third quarter, this increase in resolution caused an increase in bias. This bias is statistically grouped in two areas: continental and marine influenced areas. The bias has an impact on the uncertainty of biological models that apply the data from WRF. The pathogen model that uses summer temperatures in general has a lower quality than the crop growth model and the flowering model. Overall, it is concluded that meteorological data for commonly used vegetation models for the release of bioaerosols needs a grid resolution in the range of $9-12 \mathrm{~km}$ (or even higher) as larger grid resolutions cause substantial uncertainties. Despite the improvements due to the increase of grid resolution, there are unresolved issues in the surface processes that cause a systematic bias in the results. Therefore, some applications of temperature data in biological models require postprocessing of the simulated temperature fields. In the long term, an improvement of the surface processes and input data appear to be a better alternative.

\section{Appendices}

Applied models for the sensitivity studies on tree phenology, crop growth, and pathogen growth are as follows.

\section{A. The Simple Model for Crop Growth, Spring Barley}

The model here is based on one of the parameterisations within an agricultural management model [105] that is currently used in a number of air quality models such as DEHM [106], OML-DEP [107], and Geos-Chem [108] in relation to the atmospheric nitrogen budget [41]. The model simulates growth of spring barley and the optimal time for application of animal manure during spring (March-May) and can be used in both grid based models and on observational data [19]. The optimal time is then given by the day on which the GDD exceeds 362 degree days, where GDD is defined as

$$
\mathrm{GDD}=\sum_{i=60}^{i=151} T_{i, j}
$$

where $i$ represents the day number during spring and $j$ the station number, which in this case ranges from 1 to 300 , and temperature is in degrees Celsius.

\section{B. The Simple Model for Describing the Peak of the Birch Pollen Season}

The model here is based on a grid based model for phenological development [109] of spring flowering trees such as alder, oak, and birch [110] and implemented in the DEHM model [106], where the model uses the peak of the season and the length of the season as calibration parameters. The peak at individual sites is here calibrated against pollen observations for a number of years with the following equation:

$$
\mathrm{GDD}_{\text {peak }, j}=\sum_{i=a_{j}}^{i=n_{j}} \operatorname{Max}\left(0, T_{i, j}-T_{\text {threshold }, j}\right)
$$

where $i$ represents the day number during spring and $j$ the station number, which in this case ranges from 1 to $300 . a$ is the starting date for a particular site and $n$ is the day on which $50 \%$ of accumulated pollen has been detected at a site. For simplicity we here use the calibration parameters for Copenhagen [99], which for birch is 1400 growing degree hours, corresponding to 58 GDD (58 1400/24), and a threshold of 7 degrees Celsius. Due to the limitation on the GDD data set it was here assumed that the hourly GDH threshold at 1400 could be converted to the daily GDD threshold at 58 .

\section{The Simple Model for Pathogens, Hymenoscyphus pseudoalbidus}

The model here simulates the growth of the pathogen on ash trees during July as this is the main period for the pathogen to develop and because temperature is among the environmental factors which has the largest impact on growth of pathogens [111]. The model is here based on daily mean temperature in Celsius and a fourth order regression equation that provides colony growth in $\mathrm{mm}$ /day as function of daily mean temperatures. This approach is among the most common pathologies [68]. The regression model is based on laboratory experiments on four different sources that have been exposed to different temperatures on agar plates [66]. We have here used the mean of all four experiments to derive the regression equation on daily growth. The total growth of 
the colony (CG) during July for a number of sites is then given by

$$
\begin{aligned}
\mathrm{CG} & =\sum_{i=182}^{i=213}-2.502 * 10^{-5} * T_{i, j}^{4}+7.607 * 10^{-4} * T_{i, j}^{3} \\
& -3.899 * 10^{-3} * T_{i, j}^{2}+6.234 * 10^{-2} * T_{i, j} \\
& +1.755 * 10^{-2}
\end{aligned}
$$

where $i$ represents the day number and $j$ the station number, which in this case ranges from 1 to 300 .

\section{Conflict of Interests}

The authors declare that there is no conflict of interests regarding the publication of this paper.

\section{Acknowledgments}

This study has been supported by BBSRC, Grant no. $\mathrm{BB} / \mathrm{L} 012251 / 1$ in relation to the tree health initiative. This work was also partly funded by the Danish Research Council through a post doc grant to Carsten Ambelas Skjøth. The authors would like to thank the National Centre for Environmental Prediction (NCEP) for providing input data to the WRF/WRF-Chem model and for providing meteorological observations exchanged under the World Meteorological Organization (WMO) World Weather Watch Programme.

\section{References}

[1] M. Vieno, A. J. Dore, D. S. Stevenson et al., "Modelling surface ozone during the 2003 heat-wave in the UK," Atmospheric Chemistry and Physics, vol. 10, no. 16, pp. 7963-7978, 2010.

[2] P. Tuccella, G. Curci, G. Visconti, B. Bessagnet, L. Menut, and R. J. Park, "Modeling of gas and aerosol with WRF/Chem over Europe: evaluation and sensitivity study," Journal of Geophysical Research: Atmospheres, vol. 117, no. 3, Article ID D03303, 2012.

[3] M. Ritter, M. D. Müller, M.-Y. Tsai, and E. Parlow, "Air pollution modeling over very complex terrain: an evaluation of WRFChem over Switzerland for two 1-year periods," Atmospheric Research, vol. 132-133, pp. 209-222, 2013.

[4] J. Liao, T. Wang, X. Wang et al., "Impacts of different urban canopy schemes in WRF/Chem on regional climate and air quality in Yangtze River Delta, China," Atmospheric Research, vol. 145-146, pp. 226-243, 2014.

[5] J. Done, C. A. Davis, and M. Weisman, "The next generation of NWP: explicit forecasts of convection using the weather research and forecasting (WRF) model," Atmospheric Science Letters, vol. 5, no. 6, pp. 110-117, 2004.

[6] M. Kryza, M. Werner, K. Wałaszek, and A. J. Dore, "Application and evaluation of the WRF model for high-resolution forecasting of rainfall-a case study of SW Poland," Meteorologische Zeitschrift, vol. 22, no. 5, pp. 595-601, 2013.

[7] S. Davolio, D. Mastrangelo, M. M. Miglietta, O. Drofa, A. Buzzi, and P. Malguzzi, "High resolution simulations of a flash flood near Venice," Natural Hazards and Earth System Science, vol. 9, no. 5, pp. 1671-1678, 2009.
[8] T. Niedzielski, B. Mizinski, M. Kryza, and M. Witek, "HydroProg: a system for hydraulic forecasting in real time, based on multimodelling approach," in Meteorology, Hydrology and Water Management Research and Operational Applications, vol. 2, pp. 65-72, 2014.

[9] T. L. Otte, G. Pouliot, J. E. Pleim et al., "Linking the Eta Model with the Community Multiscale Air Quality (CMAQ) modeling system to build a national air quality forecasting system," Weather and Forecasting, vol. 20, no. 3, pp. 367-384, 2005.

[10] J. M. Baldasano, M. T. Pay, O. Jorba, S. Gassó, and P. JiménezGuerrero, "An annual assessment of air quality with the CALIOPE modeling system over Spain," Science of the Total Environment, vol. 409, no. 11, pp. 2163-2178, 2011.

[11] Y. Zhang, Y. Chen, G. Sarwar, and K. Schere, "Impact of gasphase mechanisms on Weather Research Forecasting Model with Chemistry (WRF/Chem) predictions: mechanism implementation and comparative evaluation," Journal of Geophysical Research: Atmospheres, vol. 117, no. 1, Article ID D01301, 2012.

[12] M. Stéfanon, P. Drobinski, F. D’Andrea, and N. de NobletDucoudré, "Effects of interactive vegetation phenology on the 2003 summer heat waves," Journal of Geophysical Research: Atmospheres, vol. 117, Article ID D24103, 2012.

[13] M. Falk, R. D. Pyles, S. L. Ustin et al., "Evaluated crop evapotranspiration over a region of irrigated orchards with the improved ACASA-WRF model," Journal of Hydrometeorology, vol. 15, no. 2, pp. 744-758, 2014.

[14] K. Zink, H. Vogel, B. Vogel, D. Magyar, and C. Kottmeier, "Modeling the dispersion of Ambrosia artemisiifolia L. pollen with the model system COSMO-ART," International Journal of Biometeorology, vol. 56, no. 4, pp. 669-680, 2012.

[15] J. Kukkonen, T. Olsson, D. M. Schultz et al., "A review of operational, regional-scale, chemical weather forecasting models in Europe," Atmospheric Chemistry and Physics, vol. 12, no. 1, pp. 1-87, 2012.

[16] R. Zhang, T. Duhl, M. T. Salam et al., "Development of a regional-scale pollen emission and transport modeling framework for investigating the impact of climate change on allergic airway disease," Biogeosciences, vol. 11, no. 6, pp. 1461-1478, 2014.

[17] D. Kiewra, M. Kryza, and M. Szymanowski, "Influence of selected meteorological variables on the questing activity of Ixodes ricinus ticks in Lower Silesia, SW Poland," Journal of Vector Ecology, vol. 39, no. 1, pp. 138-145, 2014.

[18] C. A. Skjøth, O. Hertel, and T. Ellermann, "Use of the ACDEP trajectory model in the Danish nation-wide Background Monitoring Programme," Physics and Chemistry of the Earth, vol. 27, no. 35, pp. 1469-1477, 2002.

[19] S. Gyldenkærne, C. A. Skjøth, O. Hertel, and T. Ellermann, "A dynamical ammonia emission parameterization for use in air pollution models," Journal of Geophysical Research: Atmospheres, vol. 110, no. 7, Article ID D07108, 2005.

[20] M. A. Hernández-Ceballos, C. A. Skjøth, H. García-Mozo, J. P. Bolívar, and C. Galán, "Improvement in the accuracy of back trajectories using WRF to identify pollen sources in southern Iberian Peninsula," International Journal of Biometeorology, vol. 58, no. 10, pp. 2031-2043, 2014.

[21] W. C. Skamarock and M. L. Weisman, "The impact of positivedefinite moisture transport on NWP precipitation forecasts," Monthly Weather Review, vol. 137, no. 1, pp. 488-494, 2009.

[22] G. Grell and A. Baklanov, "Integrated modeling for forecasting weather and air quality: a call for fully coupled approaches," Atmospheric Environment, vol. 45, no. 38, pp. 6845-6851, 2011. 
[23] A. Baklanov, K. Schlünzen, P. Suppan et al., "Online coupled regional meteorology chemistry models in Europe: current status and prospects," Atmospheric Chemistry and Physics, vol. 14, no. 1, pp. 317-398, 2014.

[24] Y. Zhang, M. Bocquet, V. Mallet, C. Seigneur, and A. Baklanov, "Real-time air quality forecasting, part I: history, techniques, and current status," Atmospheric Environment, vol. 60, pp. 632$655,2012$.

[25] G. Grell, S. R. Freitas, M. Stuefer, and J. Fast, "Inclusion of biomass burning in WRF-Chem: impact of wildfires on weather forecasts," Atmospheric Chemistry and Physics, vol. 11, no. 11, pp. 5289-5303, 2011.

[26] C. Zhao, X. Liu, L. R. Leung et al., "The spatial distribution of mineral dust and its shortwave radiative forcing over North Africa: modeling sensitivities to dust emissions and aerosol size treatments," Atmospheric Chemistry and Physics, vol. 10, no. 18, pp. 8821-8838, 2010.

[27] M. Stuefer, S. R. Freitas, G. Grell et al., "Inclusion of ash and $\mathrm{SO}_{2}$ emissions from volcanic eruptions in WRF-Chem: development and some applications," Geoscientific Model Development, vol. 6, no. 2, pp. 457-468, 2013.

[28] S. Archer-Nicholls, D. Lowe, E. Darbyshire et al., "Characterising Brazilian biomass burning emissions using WRFChem with MOSAIC sectional aerosol," Geoscientific Model Development, vol. 8, no. 3, pp. 549-577, 2015.

[29] G. C. Cuchiara, X. Li, J. Carvalho, and B. Rappenglück, "Intercomparison of planetary boundary layer parameterization and its impacts on surface ozone concentration in the WRF/Chem model for a case study in houston/texas," Atmospheric Environment, vol. 96, pp. 175-185, 2014.

[30] K. Wang, Y. Zhang, K. Yahya, S.-Y. Wu, and G. Grell, "Implementation and initial application of new chemistry-aerosol options in WRF/Chem for simulating secondary organic aerosols and aerosol indirect effects for regional air quality," Atmospheric Environment, vol. 115, pp. 716-732, 2014.

[31] A. Balzarini, G. Pirovano, L. Honzak et al., "WRF-Chem model sensitivity to chemical mechanisms choice in reconstructing aerosol optical properties," Atmospheric Environment, vol. 115, pp. 604-619, 2015.

[32] S. Archer-Nicholls, D. Lowe, S. Utembe et al., "Gaseous chemistry and aerosol mechanism developments for version 3.5.1 of the online regional model, WRF-Chem," Geoscientific Model Development, vol. 7, no. 6, pp. 2557-2579, 2014.

[33] D. Brunner, N. Savage, O. Jorba et al., "Comparative analysis of meteorological performance of coupled chemistrymeteorology models in the context of AQMEII phase 2," Atmospheric Environment, vol. 115, pp. 470-498, 2014.

[34] L. K. Berg, M. Shrivastava, R. C. Easter et al., "A new WRFChem treatment for studying regional-scale impacts of cloud processes on aerosol and trace gases in parameterized cumuli," Geoscientific Model Development, vol. 8, no. 2, pp. 409-429, 2015.

[35] Y. Zhang, X.-Y. Wen, and C. J. Jang, "Simulating chemistryaerosol-cloud-radiation-climate feedbacks over the continental U.S. using the online-coupled Weather Research Forecasting Model with chemistry (WRF/Chem)," Atmospheric Environment, vol. 44, no. 29, pp. 3568-3582, 2010.

[36] A. De Meij, E. Bossioli, C. Penard, J. F. Vinuesa, and I. Price, "The effect of SRTM and Corine Land Cover data on calculated gas and PM10 concentrations in WRF-Chem," Atmospheric Environment, vol. 101, pp. 177-193, 2015.
[37] F. J. Santos-Alamillos, D. Pozo-Vázquez, J. A. Ruiz-Arias, and J. Tovar-Pescador, "Influence of land-use misrepresentation on the accuracy of WRF wind estimates: evaluation of GLCC and CORINE land-use maps in southern Spain," Atmospheric Research, vol. 157, pp. 17-28, 2015.

[38] K. Wałaszek, M. Kryza, and M. Werner, "Evaluation of the WRF meteorological model results during a high ozone episode in SW Poland-the role of model initial conditions," International Journal of Environment and Pollution, vol. 54, no. 2-4, pp. 193202, 2014.

[39] P. W. Webley, T. Steensen, M. Stuefer, G. Grell, S. Freitas, and M. Pavolonis, "Analyzing the Eyjafjallajökull 2010 eruption using satellite remote sensing, lidar and WRF-Chem dispersion and tracking model," Journal of Geophysical Research: Atmospheres, vol. 117, Article ID D00U26, 2012.

[40] D. C. Oderbolz, S. Aksoyoglu, J. Keller et al., "A comprehensive emission inventory of biogenic volatile organic compounds in Europe: improved seasonality and land-cover," Atmospheric Chemistry and Physics, vol. 13, no. 4, pp. 1689-1712, 2013.

[41] M. A. Sutton, S. Reis, S. N. Riddick et al., "Towards a climatedependent paradigm of ammonia emission and deposition," Philosophical Transactions of the Royal Society B: Biological Sciences, vol. 368, no. 1621, 2013.

[42] A. Arneth, S. P. Harrison, S. Zaehle et al., "Terrestrial biogeochemical feedbacks in the climate system," Nature Geoscience, vol. 3, no. 8, pp. 525-532, 2010.

[43] B. C. Christner, C. E. Morris, C. M. Foreman, R. Cai, and D. C. Sands, "Ubiquity of biological ice nucleators in snowfall," Science, vol. 319, no. 5867, p. 1214, 2008.

[44] A. M. Jones and R. M. Harrison, "The effects of meteorological factors on atmospheric bioaerosol concentrations-a review," Science of the Total Environment, vol. 326, no. 1-3, pp. 151-180, 2004.

[45] Å. Dahl, C. Galán, L. Hajkova et al., "The onset, course and intensity of the pollen season," in Allergenic Pollen, M. Sofiev and K. C. Bergmann, Eds., pp. 29-70, Springer, Dordrecht, The Netherlands, 2013.

[46] T. Hickler, K. Vohland, J. Feehan et al., "Projecting the future distribution of European potential natural vegetation zones with a generalized, tree species-based dynamic vegetation model," Global Ecology and Biogeography, vol. 21, no. 1, pp. 5063, 2012.

[47] C. A. Skjøth, B. Sikoparija, S. Jäger, and EAN-Network, "Pollen sources," in Allergenic Pollen, M. Sofiev and K. C. Bergmann, Eds., pp. 9-27, Springer Netherlands, 2013.

[48] J. F. White and D. I. Bemstein, "Key pollen allergens in North America," Annals of Allergy, Asthma and Immunology, vol. 91, no. 5, pp. 425-492, 2003.

[49] C. Calfapietra, S. Fares, F. Manes, A. Morani, G. Sgrigna, and F. Loreto, "Role of Biogenic Volatile Organic Compounds (BVOC) emitted by urban trees on ozone concentration in cities: a review," Environmental Pollution, vol. 183, pp. 71-80, 2013.

[50] L. A. Darrow, J. Hess, C. A. Rogers, P. E. Tolbert, M. Klein, and S. E. Sarnat, "Ambient pollen concentrations and emergency department visits for asthma and wheeze," Journal of Allergy and Clinical Immunology, vol. 130, no. 3, pp. 630-638, 2012.

[51] S. P. Jariwala, S. Kurada, H. Moday et al., "Association between tree pollen counts and asthma ED visits in a high-density urban center," Journal of Asthma, vol. 48, no. 5, pp. 442-448, 2011.

[52] N. Khwarahm, J. Dash, P. M. Atkinson et al., "Exploring the spatio-temporal relationship between two key aeroallergens 
and meteorological variables in the United Kingdom," International Journal of Biometeorology, vol. 58, no. 4, pp. 529-545, 2014.

[53] M. Sofiev, J. Belmonte, R. Gehrig et al., "Airborne pollen transport," in Allergenic Pollen, M. Sofiev and K. C. Bergmann, Eds., pp. 127-159, Springer, Amsterdam, The Netherlands, 2013.

[54] R. M. Newnham, T. H. Sparks, C. A. Skjøth, K. Head, B. Adams-Groom, and M. Smith, "Pollen season and climate: is the timing of birch pollen release in the UK approaching its limit?" International Journal of Biometeorology, vol. 57, no. 3, pp. 391400, 2013.

[55] T. Linkosalo, H. Ranta, A. Oksanen et al., "A double-threshold temperature sum model for predicting the flowering duration and relative intensity of Betula pendula and B. pubescens," Agricultural and Forest Meteorology, vol. 150, no. 12, pp. 15791584, 2010.

[56] A. Pauling, R. Gehrig, and B. Clot, "Toward optimized temperature sum parameterizations for forecasting the start of the pollen season," Aerobiologia, vol. 30, no. 1, pp. 45-57, 2014.

[57] E. J. Cooter, J. O. Bash, V. Benson, and L. Ran, "Linking agricultural crop management and air quality models for regional to national-scale nitrogen assessments," Biogeosciences, vol. 9, no. 10, pp. 4023-4035, 2012.

[58] C. A. Skjøth, J. Sommer, L. Frederiksen, and U. Gosewinkel Karlson, "Crop harvest in Denmark and Central Europe contributes to the local load of airborne Alternaria spore concentrations in Copenhagen," Atmospheric Chemistry and Physics, vol. 12, no. 22, pp. 11107-11123, 2012.

[59] E.-C. Oerke and H.-W. Dehne, "Safeguarding production-losses in major crops and the role of crop protection," Crop Protection, vol. 23, no. 4, pp. 275-285, 2004.

[60] M. Pautasso, G. Aas, V. Queloz, and O. Holdenrieder, "European ash (Fraxinus excelsior) dieback-a conservation biology challenge," Biological Conservation, vol. 158, pp. 37-49, 2013.

[61] A. A. Appiah, P. Jennings, and J. A. Turner, "Phytophthora ramorum: one pathogen and many diseases, an emerging threat to forest ecosystems and ornamental plant life," Mycologist, vol. 18, no. 4, pp. 145-150, 2004.

[62] A. W. Frankland and P. H. Gregory, "Allergenic and agricultural implications of airborne ascospore concentrations from a fungus, Didymella exitialis," Nature, vol. 245, no. 5424, pp. 336-337, 1973.

[63] W. E. Horner, A. Helbling, and S. B. Lehrer, "Basidiomycete allergens: comparison of three Ganoderma species," Allergy, vol. 48, no. 2, pp. 110-116, 1993.

[64] T. B. Pulimood, J. M. Corden, C. Bryden, L. Sharples, and S. M. Nasser, "Epidemic asthma and the role of the fungal mold Alternaria alternata," Journal of Allergy and Clinical Immunology, vol. 120, no. 3, pp. 610-617, 2007.

[65] V. Timmermann, I. Børja, A. M. Hietala, T. Kirisits, and H. Solheim, "Ash dieback: pathogen spread and diurnal patterns of ascospore dispersal, with special emphasis on Norway," EPPO Bulletin, vol. 41, no. 1, pp. 14-20, 2011.

[66] T. Hauptman, B. Piškur, M. de Groot, N. Ogris, M. Ferlan, and D. Jurc, "Temperature effect on Chalara fraxinea: heat treatment of saplings as a possible disease control method," Forest Pathology, vol. 43, no. 5, pp. 360-370, 2013.

[67] D. J. Lovell, S. J. Powers, S. J. Welham, and S. R. Parker, "A perspective on the measurement of time in plant disease epidemiology," Plant Pathology, vol. 53, no. 6, pp. 705-712, 2004.
[68] R. D. Magarey, T. B. Sutton, and C. L. Thayer, "A simple generic infection model for foliar fungal plant pathogens," Phytopathology, vol. 95, no. 1, pp. 92-100, 2005.

[69] G. A. Grell, S. E. Peckham, R. Schmitz et al., "Fully coupled 'online' chemistry within the WRF model," Atmospheric Environment, vol. 39, no. 37, pp. 6957-6975, 2005.

[70] M. Werner, M. Kryza, C. Geels, T. Ellermann, and C. A. Skjøth, "Spatial, temporal and vertical distribution of ammonia concentrations over Europe- comparing a static and dynamic approach with WRF-Chem," Atmospheric Chemistry and Physics Discussions, vol. 15, no. 16, pp. 22935-22973, 2015.

[71] E. J. Mlawer, S. J. Taubman, P. D. Brown, M. J. Iacono, and S. A. Clough, "Radiative transfer for inhomogeneous atmospheres: RRTM, a validated correlated-k model for the longwave," Journal of Geophysical Research D: Atmospheres, vol. 102, no. 14, pp. 16663-16682, 1997.

[72] J. Dudhia, "Numerical study of convection observed during the winter monsoon experiment using a mesoscale twodimensional model," Journal of the Atmospheric Sciences, vol. 46, no. 20 , pp. 3077-3107, 1989.

[73] M. Nakanishi and H. Niino, "Development of an improved turbulence closure model for the atmospheric boundary layer," Journal of the Meteorological Society of Japan, vol. 87, no. 5, pp. 895-912, 2009.

[74] F. Chen and J. Dudhia, "Coupling an advanced land surfacehydrology model with the Penn State-NCAR MM5 modeling system. Part I: model implementation and sensitivity," Monthly Weather Review, vol. 129, no. 4, pp. 569-585, 2001.

[75] J. S. Kain and J. Kain, “The Kain-fritsch convective parameterization: an update," Journal of Applied Meteorology, vol. 43, no. 1, pp. 170-181, 2004.

[76] L. Anselin, "Local indicators of spatial association-LISA," Geographical Analysis, vol. 27, no. 2, pp. 93-115, 1995.

[77] S. Yu, R. Mathur, J. Pleim et al., "Aerosol indirect effect on the grid-scale clouds in the two-way coupled WRF-CMAQ: model description, development, evaluation and regional analysis," Atmospheric Chemistry and Physics, vol. 14, no. 20, pp. 1124711285, 2014.

[78] P. M. M. Soares, R. M. Cardoso, P. M. A. Miranda, J. de Medeiros, M. Belo-Pereira, and F. Espirito-Santo, "WRF high resolution dynamical downscaling of ERA-Interim for Portugal," Climate Dynamics, vol. 39, no. 9-10, pp. 2497-2522, 2012.

[79] T. Linkosalo, "Mutual regularity of spring phenology of some boreal tree species: predicting with other species and phenological models," Canadian Journal of Forest Research, vol. 30, no. 5, pp. 667-673, 2000.

[80] M. Kryza, K. Walaszek, M. Szymanowski, M. Werner, and A. J. Dore, "High resolution dynamical downscaling of ERA-Interim using the WRF regional climate model. Part 1: model configuration and statistical evaluation for the 1981-2010 period," Pure and Applied Geophysics, In press.

[81] E. Katragkou, M. García-Díez, R. Vautard et al., "Regional climate hindcast simulations within EURO-CORDEX: evaluation of a WRF multi-physics ensemble," Geoscientific Model Development, vol. 8, no. 3, pp. 603-618, 2015.

[82] P. A. Mooney, F. J. Mulligan, and R. Fealy, "Evaluation of the sensitivity of the weather research and forecasting model to parameterization schemes for regional climates of Europe over the period 1990-95," Journal of Climate, vol. 26, no. 3, pp. 10021017, 2013.

[83] P. M. M. Soares, R. M. Cardoso, P. M. A. Miranda, J. de Medeiros, M. Belo-Pereira, and F. Espirito-Santo, "WRF high 
resolution dynamical downscaling of ERA-interim for Portugal," Climate Dynamics, vol. 39, no. 9-10, pp. 2497-2522, 2012.

[84] U. Heikkilä, A. Sandvik, and A. Sorteberg, "Dynamical downscaling of ERA-40 in complex terrain using the WRF regional climate model," Climate Dynamics, vol. 37, no. 7-8, pp. 1551-1564, 2011.

[85] S. Galmarini and S. T. Rao, "The AQMEII two-continent regional air quality model evaluation study: fueling ideas with unprecedented data," Atmospheric Environment, vol. 45, no. 14, p. 2464, 2011.

[86] P. A. Makar, W. Gong, J. Milbrandt et al., "Feedbacks between air pollution and weather, part 1: effects on weather," Atmospheric Environment, vol. 115, pp. 442-469, 2015.

[87] S.-Y. Hong, Y. Noh, and J. Dudhia, "A new vertical diffusion package with an explicit treatment of entrainment processes," Monthly Weather Review, vol. 134, no. 9, pp. 2318-2341, 2006.

[88] M. C. Coniglio, J. Correia Jr., P. T. Marsh, and F. Kong, "Verification of convection-allowing WRF model forecasts of the planetary boundary layer using sounding observations," Weather and Forecasting, vol. 28, no. 3, pp. 842-862, 2013.

[89] C. A. Skjøth, P. V. Ørby, T. Becker et al., "Identifying urban sources as cause of elevated grass pollen concentrations using GIS and remote sensing," Biogeosciences, vol. 10, no. 1, pp. 541554, 2013.

[90] M. Sadyś, C. A. Skjøth, and R. Kennedy, "Back-trajectories show export of airborne fungal spores (Ganoderma sp.) from forests to agricultural and urban areas in England," Atmospheric Environment, vol. 84, pp. 88-99, 2014.

[91] S. Fernández-Rodríguez, C. A. Skjøth, R. Tormo-Molina et al., "Identification of potential sources of airborne Olea pollen in the Southwest Iberian Peninsula," International Journal of Biometeorology, vol. 58, no. 3, pp. 337-348, 2014.

[92] I. Orlanski, "A rational subdivision of scales for atmospheric processes," Bulletin of the American Meteorological Society, vol. 56, no. 5, pp. 527-530, 1975.

[93] M. Smith, C. A. Skjøth, D. Myszkowska et al., "Long-range transport of Ambrosia pollen to Poland," Agricultural and Forest Meteorology, vol. 148, no. 10, pp. 1402-1411, 2008.

[94] I. D. Campbell, K. McDonald, M. D. Flannigan, and J. Kringayark, "Long-distance transport of pollen into the arctic," Nature, vol. 399, no. 6731, pp. 29-30, 1999.

[95] A. Dosio and P. Paruolo, "Bias correction of the ENSEMBLES high-resolution climate change projections for use by impact models: evaluation on the present climate," Journal of Geophysical Research: Atmospheres, vol. 116, no. 16, Article ID D16106, 2011.

[96] C. Ziello, N. Estrella, M. Kostova, E. Koch, and A. Menzel, "Influence of altitude on phenology of selected plant species in the Alpine region (1971-2000)," Climate Research, vol. 39, no. 3, pp. 227-234, 2009.

[97] R. Baghi, D. Helmig, A. Guenther, T. Duhl, and R. Daly, "Contribution of flowering trees to urban atmospheric biogenic volatile organic compound emissions," Biogeosciences, vol. 9, no. 10, pp. 3777-3785, 2012.

[98] N. Helbig, B. Vogel, H. Vogel, and F. Fiedler, "Numerical modelling of pollen dispersion on the regional scale," Aerobiologia, vol. 20, no. 1, pp. 3-19, 2004.

[99] K. Zink, A. Pauling, M. W. Rotach, H. Vogel, P. Kaufmann, and B. Clot, "EMPOL 1.0: a new parameterization of pollen emission in numerical weather prediction models," Geoscientific Model Development, vol. 6, no. 6, pp. 1961-1975, 2013.
[100] D. E. Bianchi, D. J. Schwemmin, and W. H. Wagner Jr., "Pollen release in the common ragweed (Ambrosia artemisiifolia)," Botanical Gazette, vol. 120, no. 4, pp. 235-243, 1959.

[101] C. S. Reddi and N. S. Reddi, "Relation of pollen release to pollen concentrations in air," Grana, vol. 24, no. 2, pp. 109-113, 1985.

[102] M. Sofiev, U. Berger, M. Prank et al., "MACC regional multimodel ensemble simulations of birch pollen dispersion in Europe," Atmospheric Chemistry and Physics Discussions, vol. 15, no. 6, pp. 8243-8281, 2015.

[103] C. A. Skjøth and C. Geels, "The effect of climate and climate change on ammonia emissions in Europe," Atmospheric Chemistry and Physics, vol. 13, no. 1, pp. 117-128, 2013.

[104] D.-H. Kim, M. R. Doyle, S. Sung, and R. M. Amasino, "Vernalization: winter and the timing of flowering in plants," Annual Review of Cell and Developmental Biology, vol. 25, pp. 277-299, 2009.

[105] C. A. Skjøth, C. Geels, H. Berge et al., "Spatial and temporal variations in ammonia emissions-a freely accessible model code for Europe," Atmospheric Chemistry and Physics, vol. 11, no. 11, pp. 5221-5236, 2011.

[106] J. Brandt, J. D. Silver, L. M. Frohn et al., "An integrated model study for Europe and North America using the Danish Eulerian Hemispheric Model with focus on intercontinental transport of air pollution," Atmospheric Environment, vol. 53, pp. 156-176, 2012.

[107] C. Geels, H. V. Andersen, C. A. Skjøth et al., "Improved modelling of atmospheric ammonia over Denmark using the coupled modelling system DAMOS," Biogeosciences, vol. 9, no. 7, pp. 2625-2647, 2012.

[108] F. Paulot, D. J. Jacob, R. W. Pinder, J. O. Bash, K. Travis, and D. K. Henze, "Ammonia emissions in the United States, European Union, and China derived by high-resolution inversion of ammonium wet deposition data: interpretation with a new agricultural emissions inventory (MASAGE_NH3)," Journal of Geophysical Research: Atmospheres, vol. 119, no. 7, pp. 43434364, 2014.

[109] C. A. Skjøth, Integrating measurements, phenological models and atmospheric models in aerobiology-creating new concepts within aerobiological integrated monitoring and forecasting [Ph.D. thesis], Faculty of Science, Copenhagen University, København, Denmark, 2009.

[110] C. A. Skjøth, P. Baker, M. Sadyś, and B. Adams-Groom, "Pollen from alder (Alnus sp.), birch (Betula sp.) and oak (Quercus sp.) in the UK originate from small woodlands," Urban Climate, 2014.

[111] G. N. Agrios, Plant Pathology, Academic Press, San Diego, Calif, USA, 4th edition, 1997. 

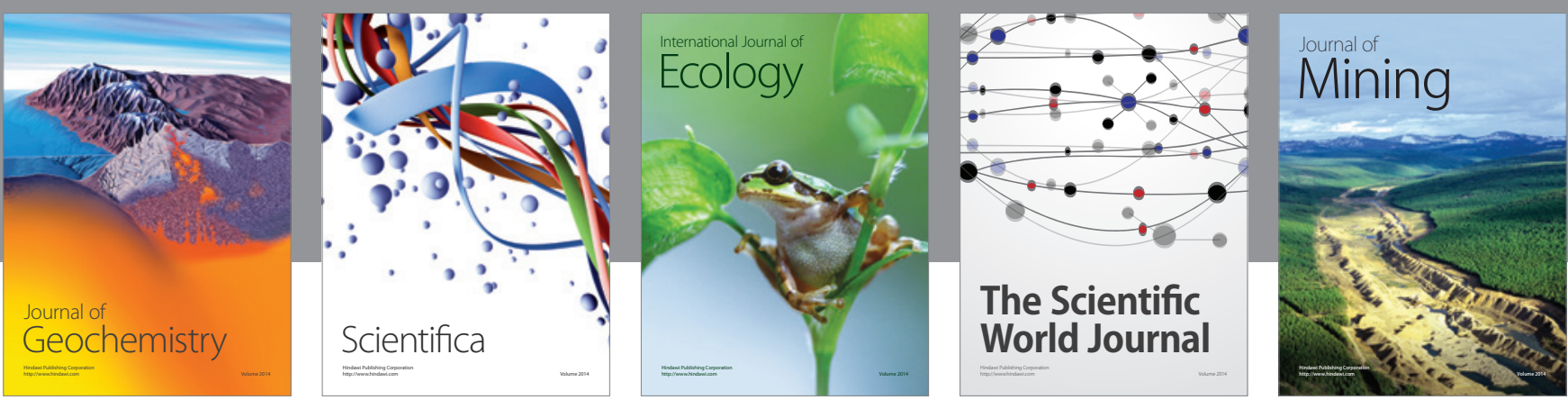

The Scientific World Journal
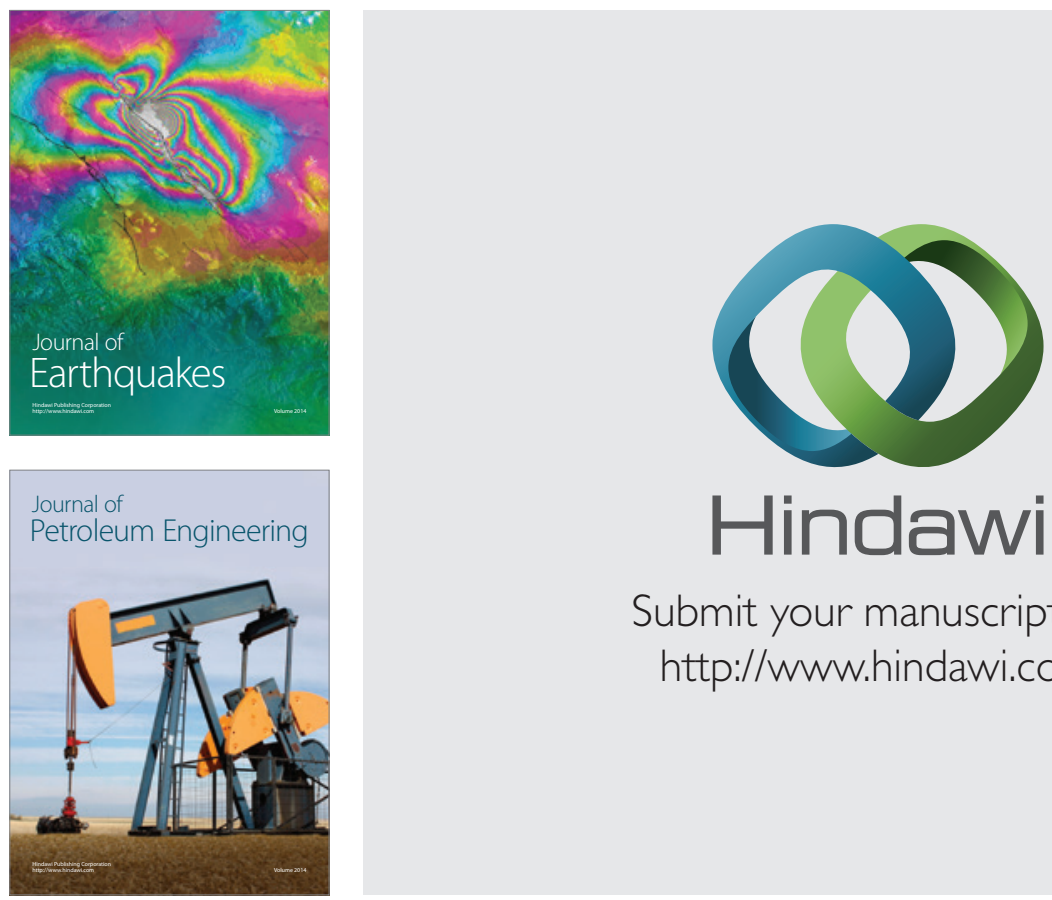

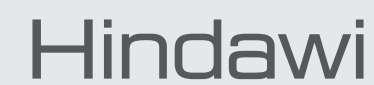

Submit your manuscripts at

http://www.hindawi.com
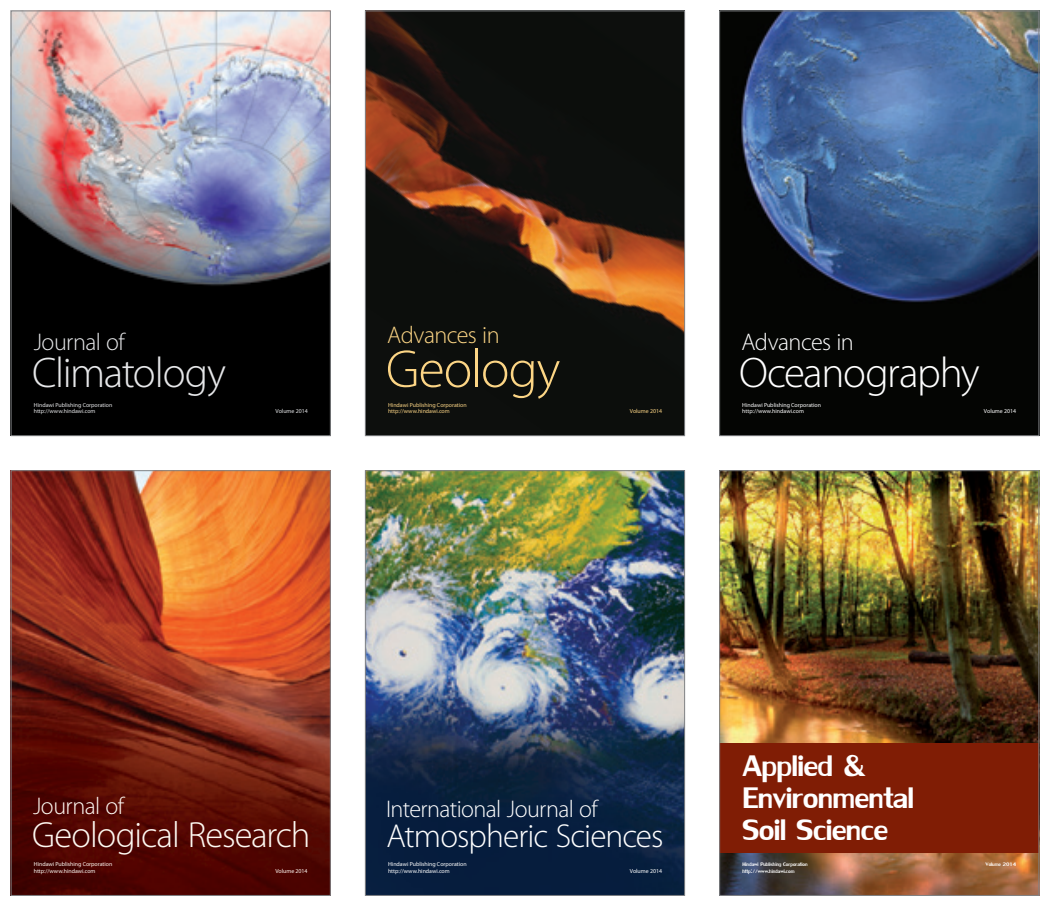
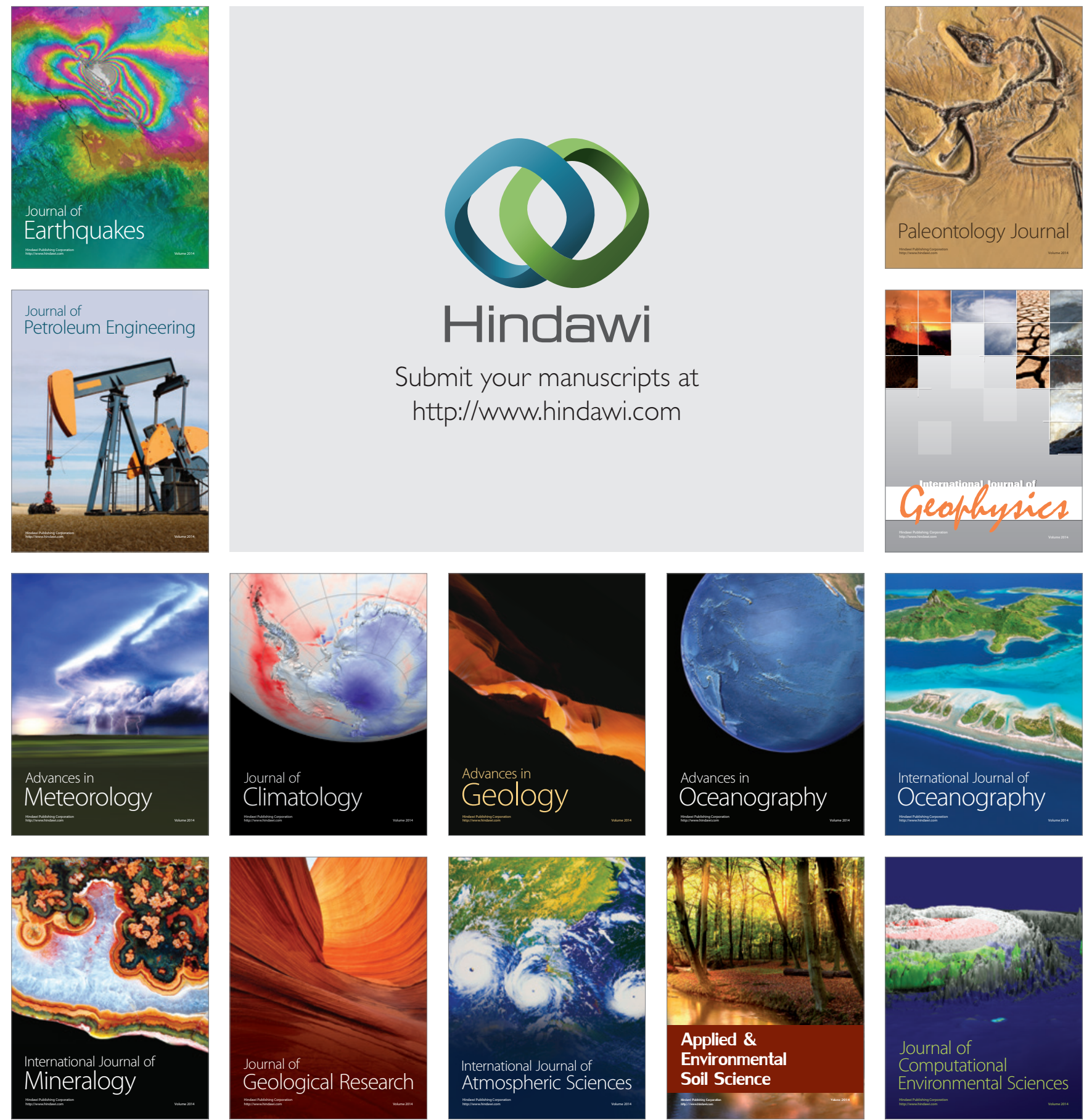